OPEN ACCESS

Edited by:

Salvador Cañigueral,

University of Barcelona, Spain

Reviewed by:

Javad Sharifi-Rad,

Shahid Beheshti University of Medical

Sciences, Iran

Víctor López,

Universidad San Jorge, Spain

*Correspondence:

Ligia Salgueiro

ligia@ff.uc.pt

Specialty section:

This article was submitted to

Ethnopharmacology,

a section of the journal

Frontiers in Pharmacology

Received: 30 March 2017

Accepted: 01 June 2017

Published: 26 June 2017

Citation:

Alves-Silva JM, Romane A, Efferth T and Salgueiro L (2017) North African Medicinal Plants Traditionally Used in

Cancer Therapy.

Front. Pharmacol. 8:383.

doi: 10.3389/fphar.2017.00383

\section{North African Medicinal Plants Traditionally Used in Cancer Therapy}

\author{
Jorge M. Alves-Silva ${ }^{1}$, Abderrahmane Romane ${ }^{2}$, Thomas Efferth ${ }^{3}$ and Ligia Salgueiro ${ }^{1 *}$ \\ ${ }^{1}$ Center for Neuroscience and Cell Biology, Institute for Biomedical Imaging and Life Sciences and Faculty of Pharmacy, \\ University of Coimbra, Coimbra, Portugal, ${ }^{2}$ Laboratoire de Chimie Organique Appliquée, Département de Chimie, Faculté \\ des Sciences (Semlalia), Université Cadi Ayyad, Marrakech, Morocco, ${ }^{3}$ Department of Pharmaceutical Biology, Institute of \\ Pharmacy and Biochemistry, Johannes Gutenberg University Mainz, Mainz, Germany
}

Background: Cancer is a major cause of mortality worldwide with increasing numbers by the years. In North Africa, the number of cancer patients is alarming. Also shocking is that a huge number of cancer patients only have access to traditional medicines due to several factors, e.g., economic difficulties. In fact, medicinal plants are widely used for the treatment of several pathologies, including cancer. Truthfully, herbalists and botanists in North African countries prescribe several plants for cancer treatment. Despite the popularity and the potential of medicinal plants for the treatment of cancer, scientific evidence on their anticancer effects are still scarce for most of the described plants.

Objective: Bearing in mind the lack of comprehensive and systematic studies, the aim of this review is to give an overview of studies, namely ethnobotanical surveys and experimental evidence of anticancer effects regarding medicinal plants used in North Africa for cancer therapy.

Method: The research was conducted on several popular search engines including PubMed, Science Direct, Scopus and Web of Science. The research focused primarily on English written papers published between the years 2000 and 2016.

Results: This review on plants traditionally used by herbalists in North Africa highlights that Morocco and Algeria are the countries with most surveys on the use of medicinal plants in folk medicine. Among the plethora of plants used, Nigella sativa and Trigonella foenum-graecum are the most referred ones by herbalists for the treatment of cancer. Moreover, a plethora of scientific evidence qualifies them as candidates for further drug development. Furthermore, we report on the underlying cellular and molecular mechanisms.

Conclusion: Overall, this review highlights the therapeutic potential of some medicinal plants as anticancer agents. The North African flora offers a rich source of medicinal plants for a wide array of diseases, including cancer. The elucidation of their modes of action represents an indispensable condition for the rational development of new drugs for cancer treatment. Furthermore, testing the anticancer activity in vivo and in clinical trials are warranted to explore the full therapeutic potential of North African plants for cancer therapy.

Keywords: anticancer, ethnobotanical, medicinal plants, North Africa, cancer 


\section{INTRODUCTION}

According to the World Health Organization (WHO) cancer represents a major cause for morbidity and mortality with $\sim 14$ million new cases in 2012 and 8 million cancer-related deaths (Forman and Ferlay, 2014). However, this burden is expected to even increase to $75 \mathrm{M}$. prevalent cases, $27 \mathrm{M}$. incident cases and 17 M. cancer-related deaths by 2030 (Adeloye et al., 2016). The cancer prevalence is gender-dependent with men presenting higher incidence rates for tumors of the lung $(16.7 \%)$, prostate (15.0\%), colorectum (10.0\%), stomach (8.5\%) and liver (7.5\%), while women reveal more cases of breast (25.2\%), colorectum (9.2\%), lung (8.7\%), cervix (7.9\%), and stomach (4.8\%). North Africa and Middle-East acquaint worldwide for 3.8\% of the new cancer cases and for $4.1 \%$ for cancer-related deaths. According to WHO, the raw incidence of cancer in Morocco was of 123.1 per 100,000 habitants in men and of 77.5 per 100,000 in women (Observatory) ${ }^{1}$ in 2012. Throughout all North African countries, the prevalence in men are higher than in women, with Egypt as country with the highest prevalence (145.9 for men and 100.5 for women) and Tunisia with the lowest prevalence (96.6 for men and 52.9 for women).

Since immemorial times, human beings acquired knowledge on the medicinal use of plants (El-Seedi et al., 2013; Ouelbani et al., 2016). Those plants have been extensively applied in folk medicine to treat ailments and diseases (El-Seedi et al., 2013) and are still used in the rural areas of developing countries (ElSeedi et al., 2013; Ouelbani et al., 2016). In fact, World Health Organization (WHO) reported that around $80 \%$ of the world population still relies on plants as source for primary health care (Cordell, 1995), while traditional medicine is the only health source available for $60 \%$ of the global population (El-Seedi et al., 2013). Medicinal plants are frequently the only form of cancer treatment for many people in North Africa, either due to low income or spatial distance from the urban treatment centers (Kabbaj et al., 2012).

The aim of this review is to compile data about the anticancer potential of plants found in ethnobotanical surveys of North African countries. The information was collected in several scientific research engines, PubMed, Science Direct, Scopus, Web of Science, and Google Scholar comprising studies conducted between 2000 and 2016.

In addition to ethnobotanical surveys, this review also includes experimental evidence on the cytotoxic effects of medicinal plants as well as their cellular and molecular mechanisms in cancer cells.

\section{ETHNOBOTANICAL STUDIES}

The ethnobotanical surveys were predominantly found in Morocco and Algeria. In other North African countries (Egypt, Tunisia, and Libya), less is known about the cytotoxic properties of medicinal plants against cancer cells. Table 1

\footnotetext{
${ }^{1}$ Observatory, G. H. Cancer, deaths per 100,000 Data by country. Available online at: http://apps.who.int/gho/data/node.main.A864?lang=en (Accessed December $17,2016)$
}

compiles the botanical information, the geographical location, the type of therapy, the cancer types investigated, the plants' parts used (e.g., leaf, aerial parts, seeds), and the preparation method (e.g., infusion, decoction). In those cases, where information was obtained from either the general population or herbalists/botanists we considered cancer therapy as monotherapy (i.e., only medicinal plants). If information was gathered from patients in cancer treatment centers the therapy was considered to be a combination of complementary and standard chemo/radiotherapy (co-therapy). The most predominant botanical families used as anticancer agents were Lamiaceae (13 species), Apiaceae (9 species), Compositae (8 species), and Fabaceae (6 species; Figure 1). Two surveys conducted at the National Institute of Oncology in Rabat (Morocco) showed that the most used plants by the patients were Nigella sativa L. (Ranunculaceae), Trigonella foenum-graecum L. (Fabaceae), Aristolochia longa L. (Aristolochiaceae), Marrubium vulgare L. (Lamiaceae), and Cassia absus L. (Fabaceae) (Kabbaj et al., 2012; Chebat et al., 2014). Recently, a review was conducted on the anticancer potential of plants used in the Arabian and Islamic world (Ahmad et al., 2016) which included N. sativa. However, this work did not mention the countries in which they are used.

The plant parts used as well as the preparation methods of anticancer agents were as diverse as the plants themselves. The most common plant parts were the seeds (23) followed by the aerial parts (20) and leaves (19) (Figure 2). Regarding the preparation methods, the most described are decoction (25), grinded with honey (20) and infusion (17) (Figure 3).

\section{SCIENTIFIC EVIDENCE AND MECHANISMS OF ACTION}

Despite the widespread use of medicinal plants in North Africa, many species still lack scientific prove of their anticancer activity. In fact, Kabbaj et al. (2012) described that 55 plants are used by patients at the National Institute of Oncology at Rabat (Morocco) albeit only 28 have been previously described for their cytotoxic properties against tumor cells. This chapter focusses, first and foremost, on (1) in vitro cytotoxicity against cancer cell lines for both volatile and non-volatile extracts and isolated major phytochemicals and (2) in vivo assays in those cases, where such studies were carried out. Afterwards, potential mechanisms of action for both extracts and isolated compounds will be reviewed, mainly cell cycle arrest, cell death induction and signal transduction pathways as well as invasiveness and migration of cancer cells.

\section{In vitro Cytotoxicity Assays}

Of all used plants in North African folk medicine, N. sativa is one of the scientifically best analyzed. A plethora of cancer cell lines have been used for the determination of cytotoxicity of medicinal plants. Of those, breast cancer cell lines (MCF-7, MCF-7/Dox and MCF-7/Topo; MDA-MB-231), colon carcinoma (HCT 116), hepatocellular carcinoma (HepG2), cervix carcinoma (Hep-2), 
TABLE 1 | Plants used by herbalists for cancer therapy in North Africa.

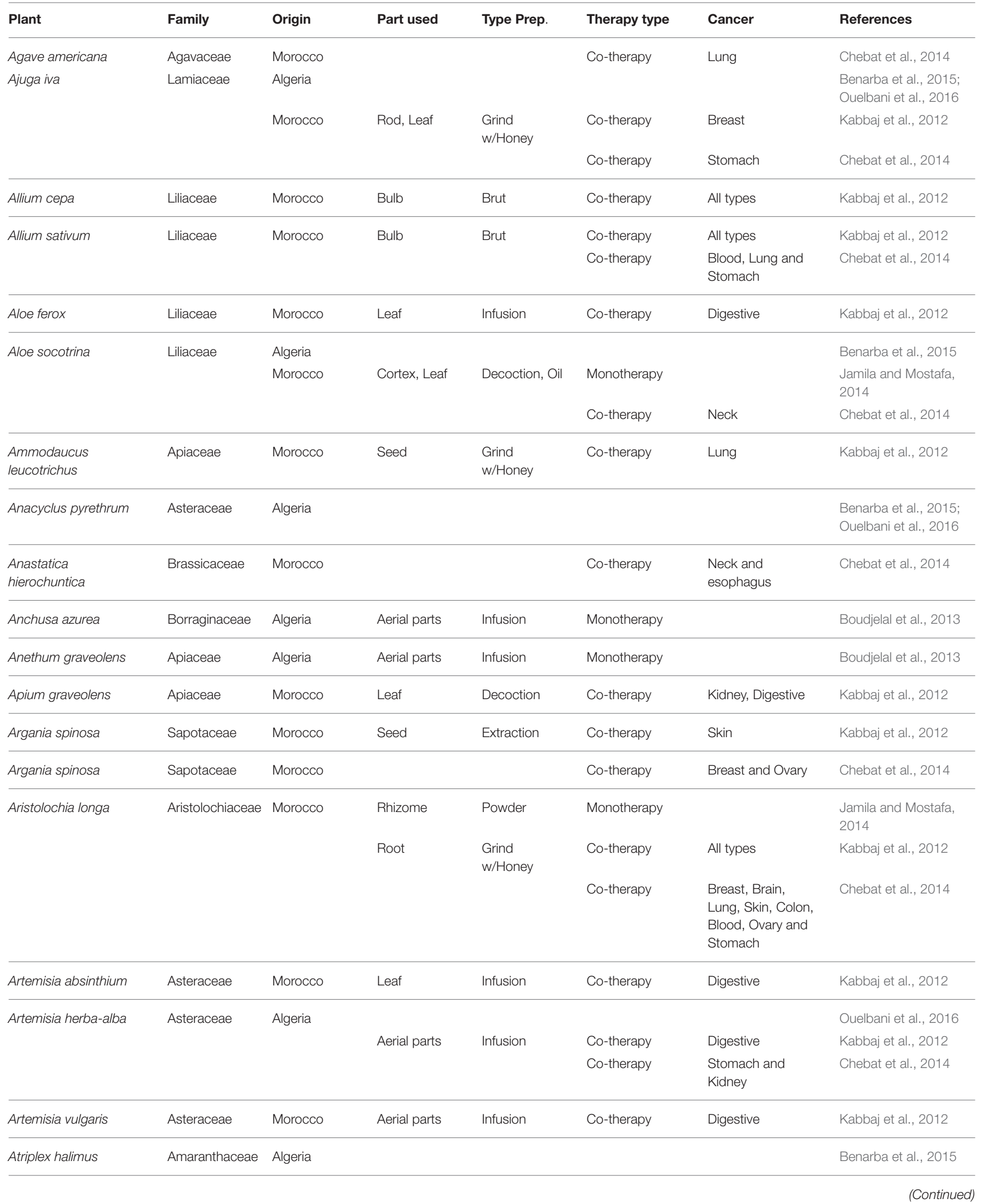


TABLE 1 | Continued

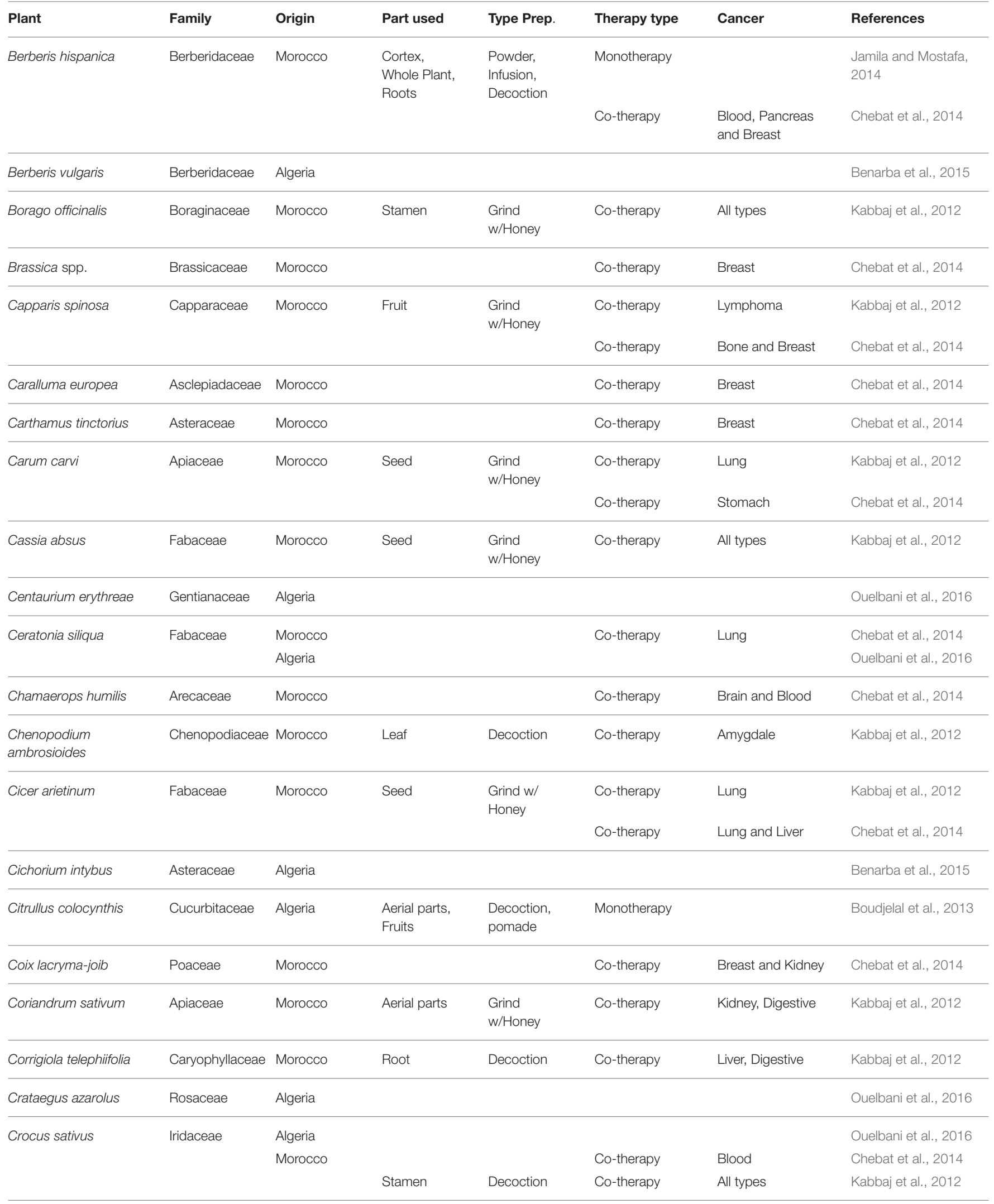


TABLE 1 | Continued

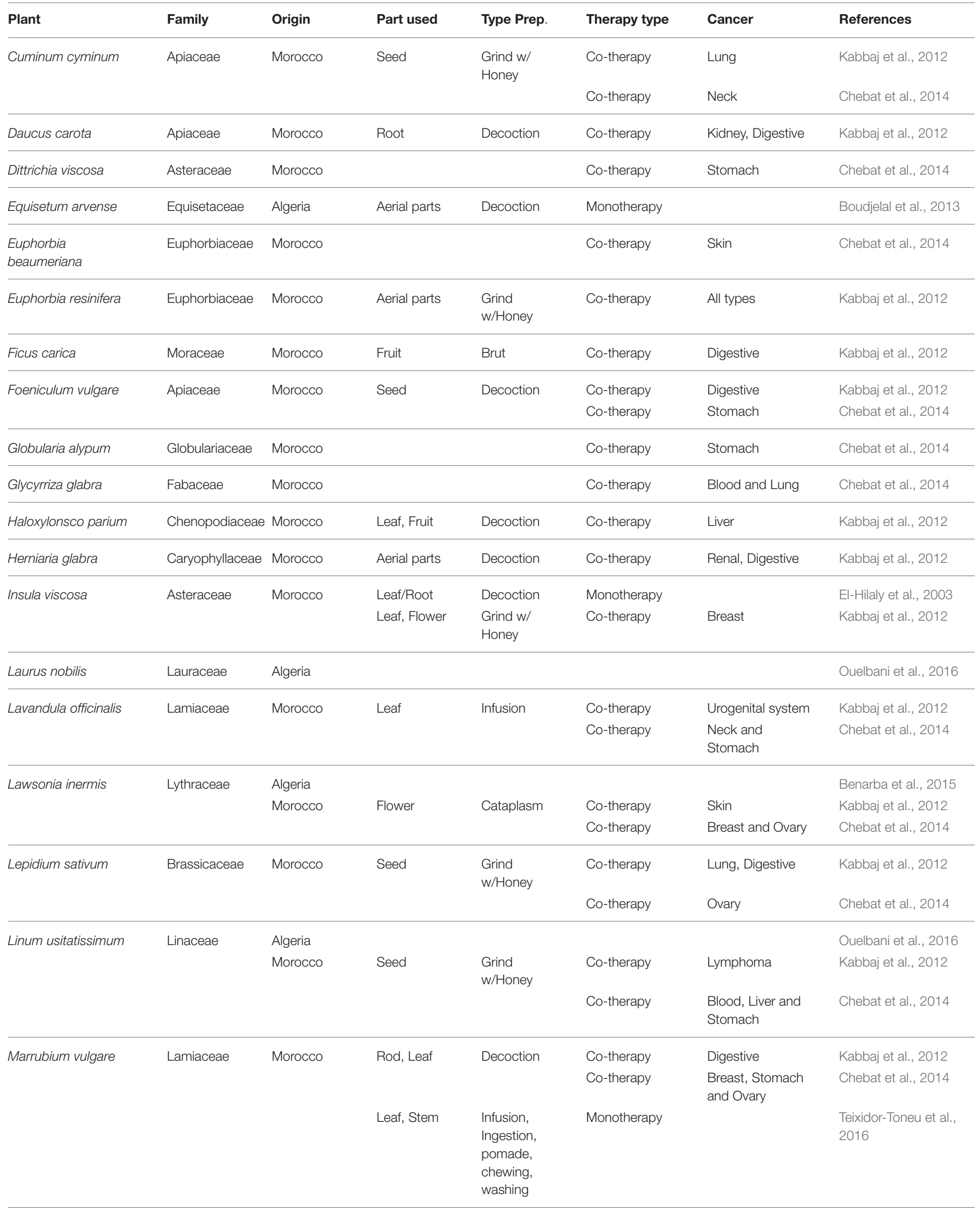


TABLE 1 | Continued

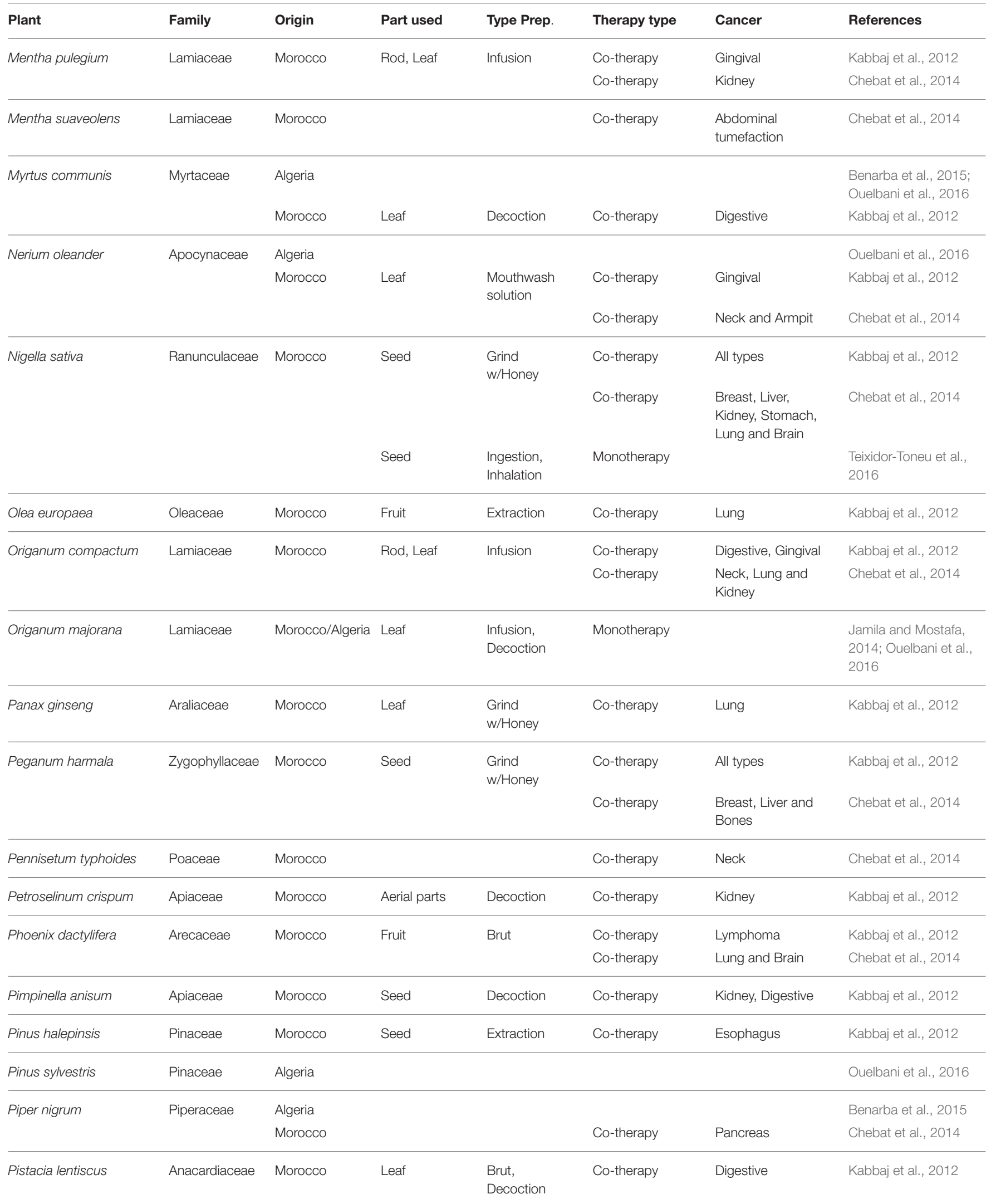


TABLE 1 | Continued

\begin{tabular}{|c|c|c|c|c|c|c|c|}
\hline Plant & Family & Origin & Part used & Type Prep. & Therapy type & Cancer & References \\
\hline Prunus persica & Rosaceae & Algeria & & & & & Benarba et al., 2015 \\
\hline Punica granatum & Lythraceae & Morocco & Rind & Decoction & Co-therapy & Skin & Kabbaj et al., 2012 \\
\hline $\begin{array}{l}\text { Rhamnus alaternus } \\
\text { subsp. alaternus }\end{array}$ & Rhamnaceae & Algeria & & & & & Ouelbani et al., 2016 \\
\hline Rheum palmatum & Polygonaceae & Algeria & Aerial Parts & $\begin{array}{l}\text { Infusion, } \\
\text { Decoction }\end{array}$ & Monotherapy & & Ouelbani et al., 2016 \\
\hline \multirow{2}{*}{ Rosmarinus officinalis } & & Morocco & Leaf & Decoction & Co-therapy & Digestive & Kabbaj et al., 2012 \\
\hline & & & & & Co-therapy & $\begin{array}{l}\text { Stomach and } \\
\text { Lung }\end{array}$ & Chebat et al., 2014 \\
\hline Salvia officinalis & Lamiaceae & Morocco & Leaf & Infusion & Co-therapy & Intestine, Lungs & Kabbaj et al., 2012 \\
\hline \multirow[t]{2}{*}{ Sesamum indicum } & Pedaliaceae & Morocco & & & Co-therapy & Breast & Chebat et al., 2014 \\
\hline & & Algeria & & & & & Benarba et al., 2015 \\
\hline Sorghum spp. & Poaceae & Morocco & & & Co-therapy & Lung & Chebat et al., 2014 \\
\hline Syzygium aromaticum & Myrtaceae & Morocco & & & Co-therapy & Bowel & Chebat et al., 2014 \\
\hline & & & & & Co-therapy & $\begin{array}{l}\text { Brain, Lung and } \\
\text { Stomach }\end{array}$ & Chebat et al., 2014 \\
\hline Triticum repens & Poaceae & Algeria & & & & & Benarba et al., 2015 \\
\hline \multirow[t]{2}{*}{ Urginea maritima } & Asparagaceae & Algeria & & & & & Ouelbani et al., 2016 \\
\hline & & Morocco & Leaf, Root & Decoction & Monotherapy & & Merzouki et al., 2000 \\
\hline Urtica dioica & Urticaceae & Algeria & & & & & Ouelbani et al., 2016 \\
\hline Verbena officinalis & Verbenaceae & Morocco & Leaf & Infusion & Co-therapy & Gallbladder & Kabbaj et al., 2012 \\
\hline Vicia faba & Fabaceae & Morocco & Seed & $\begin{array}{l}\text { Grind } \\
\text { w/Honey }\end{array}$ & Co-therapy & Lung & Kabbaj et al., 2012 \\
\hline Vitis vinifera & Vitaceae & Algeria & & & & & $\begin{array}{l}\text { Benarba et al., 2015; } \\
\text { Ouelbani et al., } 2016\end{array}$ \\
\hline \multirow[t]{2}{*}{ Zingiber officinale } & Zingiberiaceae & Morocco & Root & $\begin{array}{l}\text { Grind } \\
\text { w/Honey }\end{array}$ & Co-therapy & All types & Kabbaj et al., 2012 \\
\hline & & & & & Co-therapy & Breast & Chebat et al., 2014 \\
\hline
\end{tabular}




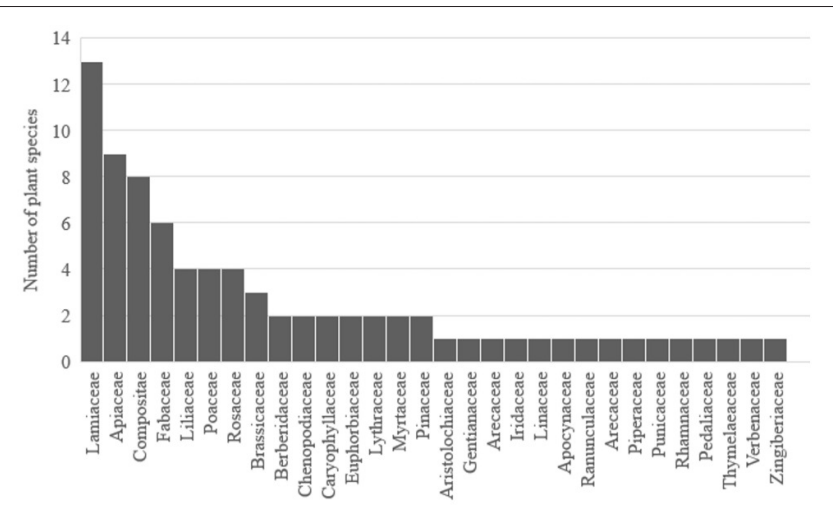

FIGURE 1 | Plant families and species traditionally used for cancer therapy in North African folk medicines.

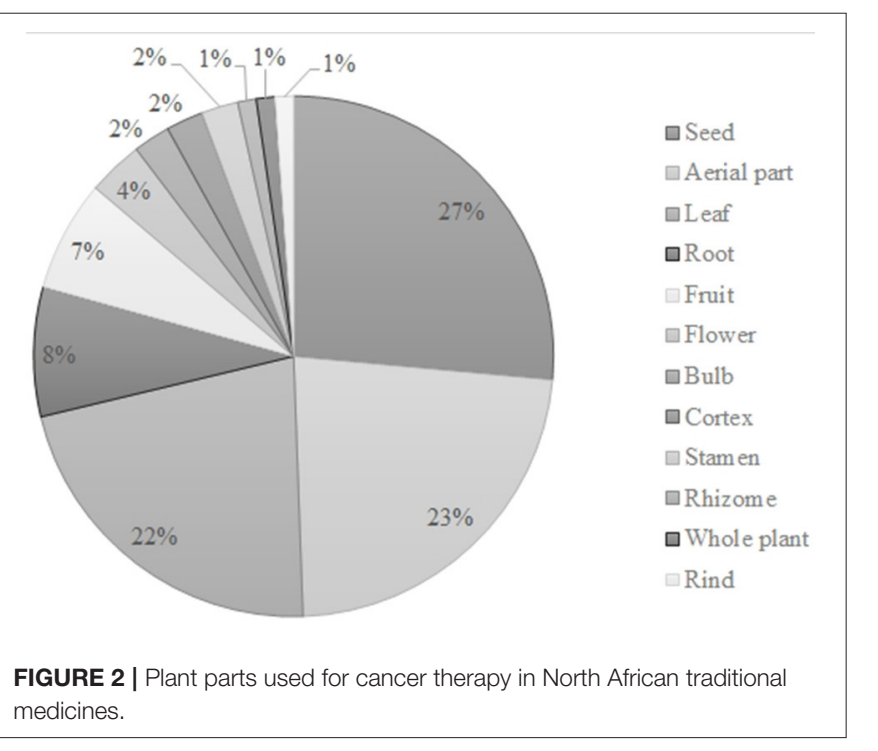

prostate cancer (PC-3), and lung carcinoma (A549) are the most commonly used ones.

\section{Nigella Sativa and Thymoquinone}

N. sativa (Ranunculaceae) is known as "Habbat Al-barakah" in Arabic and black cumin or black seed in English. This plant is widely used in Arabic medicine to treat several ailment including, but not limited to, cancer (Randhawa and Alghamdi, 2011). Seed oil from non-heated seeds of $N$. sativa decreased the growth rate of MC38 (mouse colon carcinoma) cell line by $40 \%\left(\mathrm{IC}_{50}=1.4 \mu \mathrm{g} / \mathrm{mL}\right)$, while oil from seeds heated at $50^{\circ} \mathrm{C}$ decreased the growth rate by $90 \%\left(\mathrm{IC}_{50}=0.6 \mu \mathrm{g} / \mathrm{mL}\right.$; Agbaria et al., 2015). In another study, the essential oil, an ethyl acetate and a butanol extracts were tested against several cancer cell lines. The essential oil which mainly consisted of thymoquinone $(62.17 \%)$, carvacrol $(8.29 \%)$ and 2-methyl-5prop-enyldihydroquinone and an ethyl acetate extract rich in monoxideterpenes was strongly cytotoxic against P815 ( $\mathrm{IC}_{50}$ $=0.6$ and $0.75 \%$, respectively), Vero $\left(\mathrm{IC}_{50}=0.2\right.$ and $0.22 \%$, respectively), $\mathrm{BSR}\left(\mathrm{IC}_{50}=1.2\right.$ and $0.2 \%$, respectively) and $\mathrm{ICO} 1$

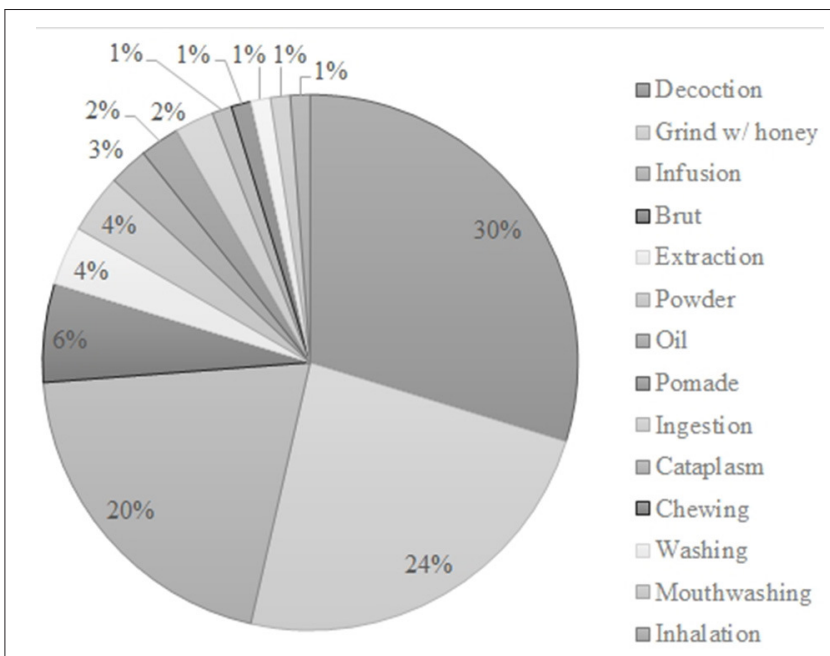

FIGURE 3 | Preparation methods ascribed in several ethnobotanical surveys in North Africa.

cells. The butanol extract, characterized by two saponosides derived from $\alpha$-amyrin, exerted weak activity against these cell lines $\left(\mathrm{IC}_{50} \sim 2 \%\right)$ except for the ICO1 cell line $\left(\mathrm{IC}_{50}=0.26 \%\right.$; Ait Mbarek et al., 2007). Several supercritical carbon dioxide extracts from the seeds of $N$. sativa were tested against HCT 116 (61.11$88.80 \%$ cell viability), MCF-7 (0.07-83.95\% cell viability), MDAMB-231 (85.58 and $88.22 \%$ cell viability), HepG2 (91.59\% cell viability), PC-3 (86.05-90.08\% cell viability) and CCD-18Co cells (69.70-88.70\% cell viability; Baharetha et al., 2013). The most potent extract $\left(60^{\circ} \mathrm{C}\right.$ and $\left.2500 \mathrm{psi}\right)$ showed a dose-dependent activity in MCF-7 cells with an $\mathrm{IC}_{50}$ value of $53.34 \pm 2.15$ $\mu \mathrm{g} / \mathrm{mL}$. An aqueous extract from the seeds decreased HepG2 cell survival $\left(\mathrm{IC}_{50}=7 \mathrm{mg} / \mathrm{mL}\right)$ and cell activity $\left(\mathrm{IC}_{50}=6 \mathrm{mg} / \mathrm{mL}\right.$; Thabrew et al., 2005). The ethyl acetate fraction obtained from an ethanolic extract from the seeds was cytotoxic toward Molt4 $\left(\mathrm{IC}_{50}=12 \mu \mathrm{g} / \mathrm{mL}\right.$ ) and P388 lymphocytic leukemia cells ( $\mathrm{IC}_{50}$ $=17 \mu \mathrm{g} / \mathrm{mL}$ ), J82 bladder carcinoma cells $\left(\mathrm{IC}_{50}=22 \mu \mathrm{g} / \mathrm{mL}\right.$ ), Wehi 184 fibrosarcoma cells $\left(\mathrm{IC}_{50}=14 \mu \mathrm{g} / \mathrm{mL}\right), \mathrm{LL} / 2$ Lewis lung carcinoma cells $\left(\mathrm{IC}_{50}=16 \mu \mathrm{g} / \mathrm{mL}\right.$ ), SW620 lymph node metastasis of colon adenocarcinoma $\left(\mathrm{IC}_{50}=18 \mu \mathrm{g} / \mathrm{mL}\right)$, and HepG2 hepatocellular carcinoma cells $\left(\mathrm{IC}_{50}=11 \mu \mathrm{g} / \mathrm{mL}\right.$; Swamy and Tan, 2000). The chloroform-methanol eluate obtained from an ethyl acetate fraction of an ethanolic extract demonstrated a selective inhibition toward HepG2 $\left(\mathrm{IC}_{50}=8 \mu \mathrm{g} / \mathrm{mL}\right)$, Molt4 $\left(\mathrm{IC}_{50}=10 \mu \mathrm{g} / \mathrm{mL}\right)$ and $\mathrm{LL} / 2$ cells $\left(\mathrm{IC}_{50}=11 \mu \mathrm{g} / \mathrm{mL}\right)$. Two extracts, aqueous and petroleum ether, were effective against both HepG2 $\left(\mathrm{IC}_{50}=300\right.$ and $710 \mu \mathrm{g} / \mathrm{mL}$, respectively $)$ and MCF-7 $\left(\mathrm{IC}_{50}=180\right.$ and $435 \mu \mathrm{g} / \mathrm{mL}$, respectively), while the chloroform extract only inhibited MCF-7 ( $\mathrm{IC}_{50}=522 \mu \mathrm{g} / \mathrm{mL}$; Sadiq et al., 2015). The essential oil from plants of Tunisia with high amounts of $p$-cymene demonstrated a dose-dependent effect against Hep-2 cell line with an $\mathrm{IC}_{50}=55.2 \mu \mathrm{g} / \mathrm{mL}$ (Jrah Harzallah et al., 2011). Another oil from Tunisian N. sativa was effective against A549 lung carcinoma and DLD-1 colon adenocarcinoma cells showing $\mathrm{IC}_{50}$ values of 43 and $46 \mu \mathrm{g} / \mathrm{mL}$, respectively (Bourgou et al., 2010). Islam et al. (2004) tested the 
anticancer efficacy of the essential oil against four stomach cancer cell lines. Of all tested lines, SCL-37'6 was the most sensitive one $\left(\mathrm{IC}_{50}=120.40 \mu \mathrm{g} / \mathrm{mL}\right)$. A different volatile extract from the seeds obtained with petroleum ether decreased the viability of A549 lung carcinoma cells exposed to concentrations above $0.1 \mathrm{mg} / \mathrm{mL}$, while an alcoholic extract only exhibited toxicity at concentrations equal or higher than $0.25 \mathrm{mg} / \mathrm{mL}$ (Al-Sheddi et al., 2014). A nanoemulsion of essential oil was cytotoxic to MCF-7 breast cancer cells in a dose- and time-dependent manner $\left(\mathrm{IC}_{50}=82\right.$ and $59 \mu \mathrm{L} / \mathrm{mL}$ for 24 and $48 \mathrm{~h}$, respectively; Periasamy et al., 2016).

The bioactive properties of $N$. sativa are usually associated with the content in thymoquinone (Figure 4, 1) (Agbaria et al., 2015) that have been widely described as anti-inflammatory, antioxidant and anti-neoplasic (Paramasivam et al., 2012; Raghunandhakumar et al., 2013; Agbaria et al., 2015). In fact, the strongest anticancer activity was achieved in seed oils heated between 50 and $150^{\circ} \mathrm{C}$ with the highest content of thymoquinone (Agbaria et al., 2015). The compound significantly inhibited the growth of Hep-2 cells in a dose-dependent manner with an $\mathrm{IC}_{50}$ of $19.25 \mu \mathrm{g} / \mathrm{mL}$ (Jrah Harzallah et al., 2011). It was also cytotoxic toward A549 lung carcinoma and DLD-1 colon adenocarcinoma cells $\left(\mathrm{IC}_{50}=13\right.$ and $5.9 \mu \mathrm{M}$, respectively; Bourgou et al., 2010). Khalife et al. (2016) described that the cytotoxic effect was doseand time-dependent $\left(\mathrm{IC}_{50}=59.2\right.$ and $68.4 \mu \mathrm{M}$, for 24 and 48 h, respectively) for HT-29 colorectal carcinoma cells. Woo et al. (2011) described the cytotoxic effect of thymoquinone against different breast cancer lines with MDA-MB-231 cells as the most susceptible ones $\left(\mathrm{IC}_{50}=11 \mu \mathrm{M}\right.$ after $\left.48 \mathrm{~h}\right)$. Several breast cancer cell lines were described as susceptible to thymoquinone in a dose- and time-dependent manner, being T-47D and MDAMB-468 the most susceptible $\left(\mathrm{IC}_{50}=18.06\right.$ and $12.30 \mu \mathrm{M}$ after 48 h, respectively; Rajput et al., 2013). Arafa et al. (2011) demonstrated that this compound inhibited cell proliferation in a doxorubicin-resistant breast cancer cell line, MCF-7/DOX (65\% inhibition after $48 \mathrm{~h}$ with $100 \mu \mathrm{M})$. It also inhibited the growth of squamous cell carcinoma cells (A431, Hep2, and RPMI 2650; Das et al., 2012). In addition, it also dose- and timedependently inhibited the growth of HCT116 colon cancer cells (Kundu et al., 2014). Alhosin et al. (2010) demonstrated that thymoquinone successfully inhibited proliferation $\left(\mathrm{IC}_{50}=24.2\right.$ $\mu \mathrm{M}$ after $24 \mathrm{~h}$ vs. $23.3 \mu \mathrm{M}$ after $48 \mathrm{~h}$ ) and viability $\left(\mathrm{IC}_{50}=24.3\right.$ $\mu \mathrm{M}$ after $24 \mathrm{~h}$ vs. $23.1 \mu \mathrm{M}$ after $48 \mathrm{~h}$ ) in p53-defected Jurkat lymphoblastic leukemia cells in a dose- and time-dependent manner. Thymoquinone was also cytotoxic to neuroblastoma Neuro-2a cells in a dose-and time-dependent manner $\left(\mathrm{IC}_{50}=40\right.$ and $36 \mu \mathrm{M}$ after 24 and $48 \mathrm{~h}$ treatment; Paramasivam et al., 2012). Racoma et al. (2013) described that thymoquinone was cytotoxic to several glioblastoma cell lines with Gli36 $\triangle \mathrm{EGFR}$ as the most susceptible one $\left(\mathrm{IC}_{50}=2.4 \mu \mathrm{M}\right)$. In another study, it was able to induce cell death in both a DNA-PKcs-wild-type (M059K) and -mutant (M059J) glioblastoma cell lines being the former more susceptible than the latter (Gurung et al., 2010). Zubair et al. (2013) demonstrated the inhibitory effect on the proliferation of different prostate cancer lines in a dose-dependent manner. Effenberger et al. (2010) investigated the anticancer activity of thymoquinone and its terpene-conjugated derivatives against several cancer cell lines. Thymoquinone demonstrated a good cytotoxicity toward 518A2 $\left(\mathrm{IC}_{50}=28.3 \mu \mathrm{M}\right), \mathrm{HL}-60\left(\mathrm{IC}_{50}=\right.$ $27.8 \mu \mathrm{M}), \mathrm{KB}-\mathrm{V} 1 / \mathrm{Vbl}\left(\mathrm{IC}_{50}=32.3 \mu \mathrm{M}\right)$ and MCF-7/Topo cells $\left(\mathrm{IC}_{50}=26.7 \mu \mathrm{M}\right)$. Conjugation with $(-)$-menthol greatly improved the effectiveness against cancer cell lines with $\mathrm{IC}_{50}$ values of 3.9, 9.0, 7.0, and 5.4 $\mu \mathrm{M}$ against 518A2, HL-60, KB$\mathrm{V} 1 / \mathrm{Vbl}$, and MCF-7/Topo, respectively. The addition of $\mathrm{C}_{6}$ spacer between the quinone and the terpene moiety decreased the anticancer activity of the compound if compared with a shorter spacer (e.g., $\mathrm{IC}_{50}=11.7$ vs. $9.0 \mu \mathrm{M}$ against HL-60) although it was stronger than thymoquinone $\left(\mathrm{IC}_{50}=11.7\right.$ vs. $27.8 \mu \mathrm{M}$ against HL-60). The addition of a $\mathrm{C}_{9}$ or higher spacers completely nullified the activity $\left(\mathrm{IC}_{50}>100\right.$ vs. $27.8 \mu \mathrm{M}$ for HL-60). By contrast, the conjugation with a betulinic acid moiety decreases the activity against all tested cell lines except HL-60 $\left(\mathrm{IC}_{50}=\right.$<smiles>CC1=CC(=O)C(C(C)C)=CC1=O</smiles>

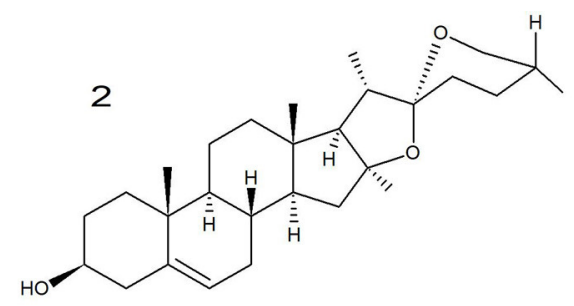<smiles>COc1ccc(-c2cc(=O)c3c(O)c(S)c(OC)cc3o2)cc1</smiles>

4<smiles>C[n+]1cccc(C(=O)[O-])c1</smiles>

3

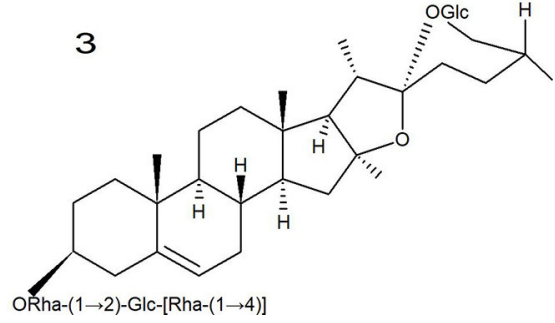

FIGURE 4 | Chemical structures of the major compounds from selected North African plants. (1) Thymoquinone from N. sativa. (2) diosgenin, (3) protodioscin, and (4) trigonelline from T. foenum-graecum, (5) ladanein from M. vulgare. 
13.7 vs. $27.8 \mu \mathrm{M})$. In contrast to the remaining compounds, the addition of a $\mathrm{C}_{6}$-spacer between the betulinic moiety and the quinone improved the cytotoxic activity of the derivative ( $\mathrm{IC}_{50}$ $=0.13$ vs. $13.7 \mu \mathrm{M}$ for HL-60). Thymoquinone demonstrated weak activity against MCF-7 cells $\left(\mathrm{IC}_{50}=109.15 \mu \mathrm{g} / \mathrm{mL}\right.$ after 72 h treatment; Dehghani et al., 2015). The nanoemulsification of this compound considerably improved the cytotoxic effect $\left(\mathrm{IC}_{50}\right.$ $=46.78 \mu \mathrm{g} / \mathrm{mL}$ after $72 \mathrm{~h}$ treatment).

\section{Trigonella Foenum-Graecum, Diosgenin, and Protodioscin}

T. foenum-graecum (Fabaceae) is known as "helba" in Arabic (Hammiche and Maiza, 2006) and fenugreek in English (AbdelBarry et al., 1997). This plant have been described as possessing several pharmacological activities, including anticancer (Yadav and Baquer, 2014). In fact, a recent paper reviews the anticancer potential of both $T$. foenum-graecum extracts and isolated compounds (El Bairi et al., 2017) describing the effects on the major hallmarks of cancer, sustaining proliferative signaling, angiogenesis, cell death evasion, tumor promoting inflammation, invasion, and metastasis and genomic instability. A water extract obtained from the seeds was cytotoxic toward several cancer cell lines (T-cell lymphoma, B-cell lymphoma, thyroid papillary carcinoma, and breast cancer; Alsemari et al., 2014). A crude methanol extract from the seeds induced cell death in a dose-dependent manner $\left(\mathrm{IC}_{50}=1,000 \mu \mathrm{g} / \mathrm{mL}\right.$; Khalil et al., 2015), however, significant inhibition was achieved only at concentrations of $100 \mu \mathrm{g} / \mathrm{mL}$. Seed extracts were cytotoxic to a plethora of breast, pancreatic and prostate cancer cell lines (Shabbeer et al., 2009). Crude extracts of fenugreek decreased the cell viability toward both drug-sensitive and drug-resistant cancer cell lines (Saeed et al., 2015). Methanol extracts from the whole plant induced cytotoxicity in MCF-7 breast cancer cells $\left(\mathrm{IC}_{50}=65 \mu \mathrm{g} / \mathrm{mL}\right.$; Alshatwi et al., 2013). In the same cell model, a chloroform extract also induced cytotoxicity $\left(\mathrm{IC}_{50}=\right.$ $41.6 \mu \mathrm{g} / \mathrm{mL}$; Khoja et al., 2011). Both aqueous and ethanolic extracts exerted cytotoxic effects against MCF-7 cells in a doseand time-dependent manner (Sebastian and Thampan, 2007), while an ethanolic extract induced cell death in Jurkat leukemia cells (Al-Daghri et al., 2012). Seed oil from fenugreek induced cytotoxicity toward several cancer cell lines [HEp2 (human epidermoid cancer cells), WISH, and MCF-7; Al-Oqail et al., 2013].

Diosgenin (Figure 4, 2), the major compound of fenugreek, reduced cell proliferation in a time- and dose-dependent manner in HT-29 colon cancer cells (Raju et al., 2004). Furthermore, it induced cell death to several breast, pancreatic and prostate cancer cell lines (Shabbeer et al., 2009). In PC-3 prostate cancer cells, it inhibited the growth at $50 \mu \mathrm{M}$ in a timedependent manner (Chen et al., 2011). Diosgenin (25 $\mu \mathrm{M})$ induced cytotoxicity and inhibited cell proliferation in KBM-5 cells (Shishodia and Aggarwal, 2006). Furthermore, co-treatment with chemotherapeutic agents potentiated the cytotoxic effect of the latter. The saponin revealed inhibitory effects on several squamous cell carcinomas (Das et al., 2012). Diosgenin inhibited the growth of A549 lung cancer cells in a dose- and timedependent manner (47 and $43 \mu \mathrm{M}$ after $72 \mathrm{~h}$, respectively;
Rahmati-Yamchi et al., 2014). Treatment with diosgenin induced cell death in HEL erythroleukemia cells (90\% inhibition at $40 \mu \mathrm{M}$ after 48 h; Leger et al., 2004). In a different leukemia model, K562, it also induced cytotoxicity $\left(\mathrm{IC}_{50}=15 \mu \mathrm{M}\right.$; Liu et al., 2005). The 1547 osteosarcoma cell line is susceptible to this compound (86\% inhibition at $40 \mu \mathrm{M}$ for $24 \mathrm{~h}$; Moalic et al., 2001).

Protodioscin (Figure 4, 3), isolated from fenugreek, inhibited the growth of HL-60 leukemic cells (100\% inhibition at $10 \mu \mathrm{M})$, while demonstrating poor inhibitory effects against KATO III gastric cancer cells (42.5\% at $10 \mu \mathrm{M}$; Hibasami et al., 2003). In addition, this compound was cytotoxic toward 60 cell lines from the National Cancer Institute $\left(\mathrm{IC}_{50}=1.64->100 \mu \mathrm{M}\right.$; Hu and Yao, 2002). Furthermore, it was cytotoxic in a dose-dependent manner toward HCT116 $\left(\mathrm{IC}_{50}=2.26 \mu \mathrm{M}\right)$, HT-29 $\left(\mathrm{IC}_{50}=3.48\right.$ $\mu \mathrm{M})$, SW480 and EMT6 $\left(\mathrm{IC}_{50}=6.68 \mu \mathrm{M}\right)$ and DU145 cells $\left(\mathrm{IC}_{50}\right.$ $=>28.63 \mu \mathrm{M}$; Manase et al., 2012).

\section{Aristolochia Longa}

A. longa (Aristolochiaceae) is known as "Berrostom" in Algeria. This plant is widely used in traditional medicine including cancer treatment (Benarba et al., 2016). Nevertheless, very few studies have been conducted on the anticancer activity of this plant. An aqueous extract of $A$. longa reduced cell viability of BL41 Burkitt's lymphoma cells ( $\mathrm{IC}_{50}=15.63 \mu \mathrm{g} / \mathrm{mL}$; Benarba et al., 2012) as well as of two triple-negative breast cancer cell lines, MDA-MB$231\left(\mathrm{IC}_{50}=97 \mu \mathrm{g} / \mathrm{mL}\right)$ and HBL100 $\left(\mathrm{IC}_{50}=40 \mu \mathrm{g} / \mathrm{mL}\right.$; Benarba et al., 2016).

\section{Marrubium Vulgare and Ladanein}

M. vulgare (Lamiaceae) is known as "merriwa" (Tahraoui et al., 2007), "ifzi” (Teixidor-Toneu et al., 2016), "amarriw” or "ifza" (Merzouki et al., 2000), "marrîwet” (Kabbaj et al., 2012) in several Arab-speaking countries or as "horehound" in English (Tahraoui et al., 2007). This plant is widely used as treatment for several ailments including cancer (Paunovic et al., 2016). Indeed, the essential oil from $M$. vulgare decreased the cell viability in a dosedependent manner $\left(\mathrm{IC}_{50}=0.258 \mu \mathrm{g} / \mathrm{mL}\right.$; Zarai et al., 2011). An ethanolic extract obtained from $M$. vulgare exerted cytotoxicity in a dose-dependent manner in B16 melanoma and U251 glioma cells (Paunovic et al., 2016).

Ladanein (Figure 4, 5), a compound found in M. vulgare have been described as having cytotoxic effect toward several cell lines, $\mathrm{DA} 1-3 \mathrm{~b} / \mathrm{M} 2\left(\mathrm{IC}_{50}=10.4 \mu \mathrm{M}\right), \mathrm{K} 562\left(\mathrm{IC}_{50}=25.1 \mu \mathrm{M}\right), \mathrm{K} 562 \mathrm{R}$ and 697 ( $\mathrm{IC}_{50}=38 \mu \mathrm{M}$; Alkhatib et al., 2010).

\section{In vivo Cytotoxicity}

In vitro results can be taken as first clue for bioactivity, but they do not necessarily reflect activity in living organisms. Biotransformation in the liver degrades many natural products so that they finally lose activity in vivo (Reichling et al., 2009).

\section{Nigella sativa and Thymoquinone}

The essential oil of $N$. sativa reduced solid tumor volume in mice in a dose-dependent manner $\left(2.5 \mathrm{~cm}^{3}\right.$ for untreated vs. 0.22 and $0.16 \mathrm{~cm}^{3}$ for 30 and $50 \mu \mathrm{L} /$ mouse, respectively). In addition, it reduced cancer metastasis (14 for untreated mice vs. 2 and 0 for 
30 and $50 \mu \mathrm{L} /$ mouse, respectively) and improved survival of mice (83\% mortality in untreated group vs. 16.6 and $0 \%$ for 30 and 50 $\mu \mathrm{L} /$ mouse, respectively; Ait Mbarek et al., 2007). Thymoquinone significantly decreases the tumor size and mass in a sarcoma 180bearing mice xenograft model (Das et al., 2012). In addition, it inhibited angiogenesis as observed by a decrease of CD31 expression.

\section{Trigonella Foenum-Graecum and Diosgenin}

An aqueous extract from the seeds of fenugreek slowed the progression of DMBA-induced breast cancer (40 vs. $80 \%$ incidence; Amin et al., 2005). Furthermore, it decreased the mean tumor number ( 2.0 vs. 3.5 ) and weight ( $3.0 \mathrm{~g}$ vs. $5.0 \mathrm{~g}$ ) in rats. The histology was also markedly different with the extract-treated rats bearing only mild-to-moderate hyperplasia. Supplementation with $0.01 \%$ fenugreek seed powder for 8 weeks decreased total colonic aberrant crypt foci, while continuously feeding rats with fenugreek seed powder decreased multicrypt foci in azoxymethane-induced aberrant crypt foci formation (Raju et al., 2004). These effects were observed both in the initiation and promotion stages of carcinogenesis. Seed extract was given at pre-initiation, post-initiation, promotion, and throughout all stages to a DMBA+TPA-induced mouse skin carcinogenesis model (Chatterjee et al., 2012). The treatment decreased the cumulative papilloma count compared to control. Furthermore, it decreased cancer incidence and tumor burden. In addition, it decreased the latent period. A methanol extract reduced the number of mice bearing tumors (13 vs. 18 for untreated control), the tumor incidence (65 vs. $90 \%$ for untreated), the average number of tumors (102 vs. 221 for untreated control mice) and tumor multiplicity (7.84 vs. 12.27 for untreated) in a DMBATPA-induced skin carcinogenesis model (Ali et al., 2014). Pretreatment of mice inoculated with Ehrlich ascites carcinoma (EAC) with an alcoholic extract of fenugreek decreased the number of EAC cell count per mouse $\left(0.208 \times 10^{6}\right.$ at $200 \mathrm{mg} / \mathrm{kg}$ i.p. vs. $4.42 \times 10^{6}$; Sur et al., 2001). Furthermore, post-treatment also decreased the EAC cell count per mouse $\left(0.41 \times 10^{7}\right.$ at 200 $\mathrm{mg} / \mathrm{kg}$ i.p. vs. $1.68 \times 10^{7}$ ).

The supplementation with $0.1 \%$ diosgenin, the major compound of fenugreek, decreased both total colonic aberrant crypt foci and multicrypt foci in azoxymethane-induced aberrant crypt foci formation on initiation and promotion stages (Raju et al., 2004). Diosgenin is able to decrease tumor mass and size in mice bearing sarcoma 180 (Das et al., 2012). Furthermore, it decreased the expression of CD31, suggesting that diosgenin revealed antiangiogenic effects in vivo.

\section{Cell Cycle Perturbations}

The effect of cytotoxic compounds is frequently measured by detection of cellular DNA with propidium iodide and subsequent measurement by flow cytometry. The resulting DNA histograms show the distribution of cell populations in the cell cycle. Anticancer compounds at subtoxic concentrations frequent led to an arrest of the cell cycle in the G1, S, or G2/M phase resembling cytostatic effects. Cytotoxicity of compounds results in cell death, which appears as dead cell fragments below the G0/G1 fraction. Hence, flow cytometric measurements can deliver data on both cytostatic and cytotoxic effects of anticancer substances. Cell cycle is a highly-regulated process by the sophisticated activity of cyclin-dependent kinases (CDKs). This type of kinases are activated by the presence of cyclins and de-activated by the presence of CDK inhibitors (Bassermann et al., 2014). The type of CDK-cyclin complex is dependent on extracellular signals as well as intrinsic information. The CDK inhibitors belong to two different families, the INK4 and CIP/KIP proteins. The first group interacts with CDK4/6 kinases inhibiting the capacity to bind to D-type cyclins, e.g., p16 ${ }^{\mathrm{INK} 4 \mathrm{a}}$, while the latter binds to CDK-cyclin complexes, such p21 ${ }^{\mathrm{Cip} 1}$ and p57 ${ }^{\text {Kip2 }}$ (Yun et al., 2013; Ruijtenberg and van den Heuvel, 2016). CDK inhibitors such as p21, p27, and p53 are tumor suppressor genes that block both cell proliferation and migration (Yun et al., 2013). Due to the importance of cell cycle progression for tumor development, several authors have described the cell cycle arrest capacity of plant extracts as well as isolated major compounds. In Figure 5 the effects of the extracts and major phytochemicals (thymoquinone, diosgenin and protodioscin) on cell cycle are represented.

\section{Thymoquinone}

To the best of our knowledge, no studies addressing the cell cycle arrest capacities of whole extracts or oils from $N$. sativa were conducted to the date. Thus, only studies with its major compound (thymoquinone) will be referred. Thymoquinone was able to cause cell cycle arrest at S phase (Khalife et al., 2016). By contrast, Woo et al. (2011) described that this compound caused accumulation of cells in the sub-G1 phase without effect on p53 activation. This compound caused cell cycle arrest at G1 after $24 \mathrm{~h}$, but accumulated cells in the sub-G1 phase after $48 \mathrm{~h}$ treatment. Furthermore, thymoquinone induced the expression of p27 and p53, but downregulated the expression of cyclin D1 and E (Rajput et al., 2013). It caused the accumulation of sub-G1 cells (25.6 vs. $1.3 \%$ in untreated cells; Arafa et al.,

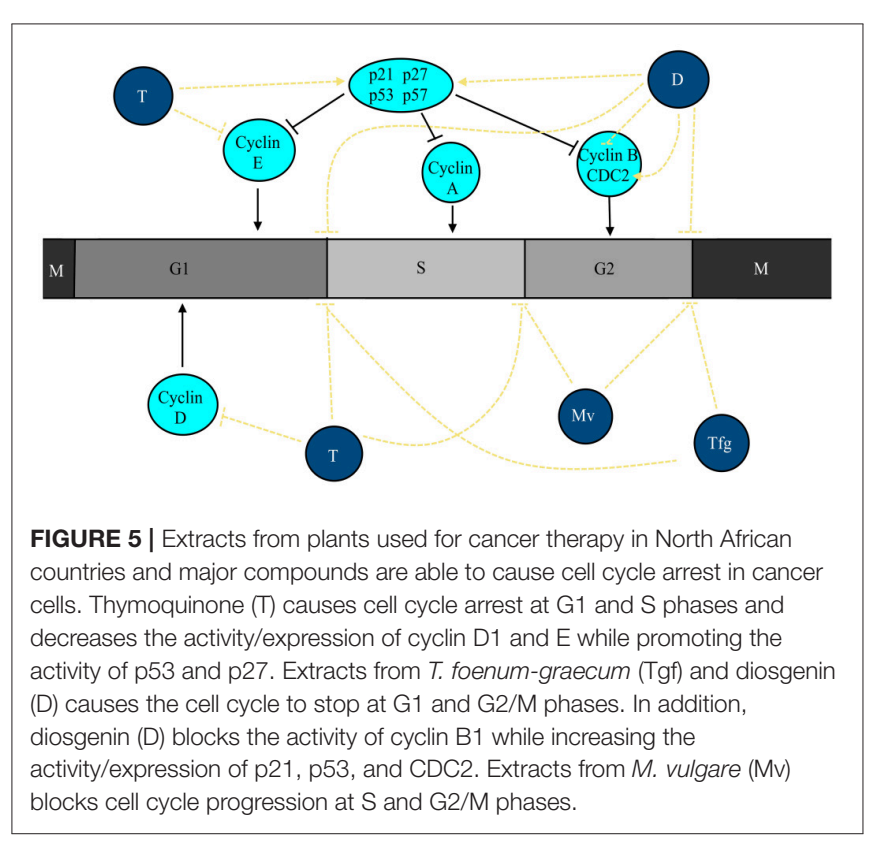


2011). In p53-defective Jurkat lymphoblastic leukemia cells, the compound caused cell accumulation in sub-G1 (Alhosin et al., 2010). Gurung et al. (2010) described an accumulation in the sub-G1 phase in DNA-PKcs-normal (M059K) and -defective (M059J) glioblastoma cell lines. Thymoquinone also increased the sub-G1 fraction in U266 multiple myeloma cells (Li et al., 2010).

\section{Trigonella Foenum-Graecum and Diosgenin}

A crude methanol extract of fenugreek seeds drove cells into the sub-G1 $(\sim 49.1 \%)$ and G1 phase $(65 \%$ cells) in HepG2 (Khalil et al., 2015). In pancreatic cancer cells, fenugreek exerted two different effects. In both LNCaP and PC-3 cell lines, it increased accumulation of cells in sub-G1, while in PC-3 cells it also caused cell cycle arrest in the G2/M phase (Shabbeer et al., 2009). An ethanolic extract caused an increase of the sub-G1 fraction $(30.1 \%$ at $100 \mu \mathrm{g} / \mathrm{mL})$ as well as a cell cycle arrest at G2/M (Sebastian and Thampan, 2007). Diosgenin, a saponin isolated from fenugreek, caused sub-G1 accumulation after $48 \mathrm{~h}$ at $50 \mu \mathrm{M}$ (51 vs. 9\% for untreated cells; Shishodia and Aggarwal, 2006). Similarly, the treatment of squamous cell carcinomas with diosgenin caused an increase of the sub-G1 fraction (Das et al., 2012). The saponin causes cell cycle arrest at $\mathrm{G} 2 / \mathrm{M}$ phase as soon as after $6 \mathrm{~h}$ of treatment $(22.9$ vs. $17.6 \%)$ due to an increase in the expression of p21, while after $24 \mathrm{~h}$ of treatment there was also an accumulation in the subG1 phase (Leger et al., 2004). After $36 \mathrm{~h}$ treatment diosgenin $(20 \mu \mathrm{M})$ caused cell cycle arrest at G2/M with concomitant decrease in cyclin B1 and p21, and increase in cdc2 in K562 (Liu et al., 2005). In NB4 cells, diosgenin also caused arrest at the G2/M phase with an increase in p53 expression. Furthermore, after $48 \mathrm{~h}$ the arrest changed to sub-G1 phase accumulation simultaneously with DNA fragmentation. Diosgenin treatment up to $24 \mathrm{~h}$, arrested cells in the G1 phase (50 vs. $35 \%$ ) with an associated decrease of cells in the S phase (21 vs. $46 \%$ ) in 1547 osteosarcoma cells (Moalic et al., 2001). At 48 h, a sub-G1 peak appeared. Concomitantly, an upregulation of p21 and p53 was observed.

\section{Marrubium vulgare}

An ethanolic extract of $M$. vulgare caused DNA fragmentation in a time-dependent manner (Paunovic et al., 2016) in B16 and U251 cell lines. Furthermore, it caused cell cycle arrest at the S and $\mathrm{G} 2 / \mathrm{M}$ phases.

\section{Cell Death Induction}

Apoptosis is a genetically programmed cell death with two main pathways, an intrinsic pathway characterized by the release of cytochrome $c$ and posterior activation of caspase-9, and an extrinsic pathway characterized by the ligation of a death ligand (Walsh, 2014). While apoptosis controls whole cells, autophagy is a catabolic process in which intracellular organelles and macromolecules undergo destruction and recycling (Lapierre et al., 2015). In Figure 6 the effects of extracts from North African plants and isolated compounds (thymoquinone, diosgenin and protodioscin) in cell death by apoptosis are shown.

\section{Nigella Sativa and Thymoquinone}

A supercritical carbon dioxide extract obtained from the seeds of black cumin increased caspase- 3 and-7 levels by 2- and 1.5-fold at 100 and $80 \mu \mathrm{g} / \mathrm{mL}$, respectively, in MCF-7 breast cancer cells. At $100 \mu \mathrm{g} / \mathrm{mL}$, it also increased caspase- 8 levels by 2 -fold. The extract increased the apoptotic index (5.65\% untreated cells vs. $52.37 \%$ at $60 \mu \mathrm{g} / \mathrm{mL}$; Baharetha et al., 2013). Thabrew et al. (2005) demonstrated that an aqueous extract inhibited DNA $\left(\mathrm{IC}_{50}=3\right.$ $\mathrm{mg} / \mathrm{mL}$ ) and protein synthesis in HepG2 cells. A nanoemulsion of essential oil caused cell death by either apoptosis $(\sim 44 \%$ after $24 \mathrm{~h}$ ) and necrosis ( $\sim 28 \%$ after $24 \mathrm{~h}$; Periasamy et al., 2016). Thymoquinone, the major compound of $N$. sativa, caused DNA fragmentation, induced apoptosis (36\% vs. $2.5 \%$ after $48 \mathrm{~h}$ ), induced the expression of caspase- 8 precursor, and downregulated procaspases-3 (Khalife et al., 2016). Furthermore, decreased the levels of procaspase- $8,-9$ and -7 as well as the protein and mRNA levels of $\mathrm{Bcl}-2, \mathrm{Bcl}-\mathrm{xL}$ and survivin in a time-dependent manner while increasing the Bax/Bcl-2 ratio (Woo et al., 2011). Dastjerdi et al. (2016) suggested that thymoquinone induced apoptosis in MCF-7 cells in a p53- and time-dependent manner. In addition, this compound caused DNA fragmentation and morphological changes associated with apoptosis and disrupted the mitochondrial membrane potential, decreased the $\mathrm{Bcl} 2 / \mathrm{Bax}$ ratio and activated caspases-3, -7 , and -9 (Arafa et al., 2011). Furthermore, it triggered the release of cytochrome $\mathrm{c}$ from mitochondria, increased the expression of pro-apoptotic Bax proteins and downregulated the expression of the anti-apoptotic proteins Bcl2 and survivin (Rajput et al., 2013). Rooney and Ryan (2005) demonstrated that the proapoptotic effects are mediated by glutathione (GSH) depletion, since the pre-treatment with buthioninesulfoximine, a selective inhibitor of GSH, increased the number of apoptotic cells (31.7 vs. $55.1 \%)$. On the other hand, this effect was caspase-3-dependent, since the number of apoptotic cells decreased 4.9-fold after treatment with a caspase-3 inhibitor (41.1 vs. $8.4 \%)$. Kundu et al. (2014) reported that it induced apoptosis in HCT116 cells by decreasing the levels of $\mathrm{Bcl}-2$ and $\mathrm{Bcl}-\mathrm{xL}$, but increasing $\mathrm{Bax}$ levels. Furthermore, it cleaved caspases-9, -7, -3 and PARP and activated caspase-3. Treating a neuroblastoma cell line, Neuro$2 \mathrm{a}$, with thymoquinone downregulated the mRNA and protein levels of $\mathrm{Bcl}-2$, upregulated the mRNA and protein levels of Bax, caused a loss of mitochondria membrane potential and triggered the release of cytochrome $\mathrm{c}$ to the cytosol. In addition, it activated caspases- 3 and -9 with concomitant increase in PARP, while decreasing the protein levels of XIAP, a selective inhibitor for caspases-3, -7, and -9 . All of them are signals that lead to cell death by apoptosis (Paramasivam et al., 2012). By contrast, the compound induced cell death by autophagy inhibition in glioblastoma cells lines (Racoma et al., 2013). The treatment increase LC3-II and p62 without changing the levels of Beclin1. Concomitantly, vacuolization of cells, disruption of lysosomal membrane and modulation of lysosome location within the cell was observed. Furthermore, the compound activated cathepsin and induced caspase-independent cell death induction. In DNAPKcs-normal and defective glioblastoma cell lines, the treatment triggered the release of cytochrome $c$ to the cytosol, induced apoptotic cell death rather than necrosis, caused DNA damage, 


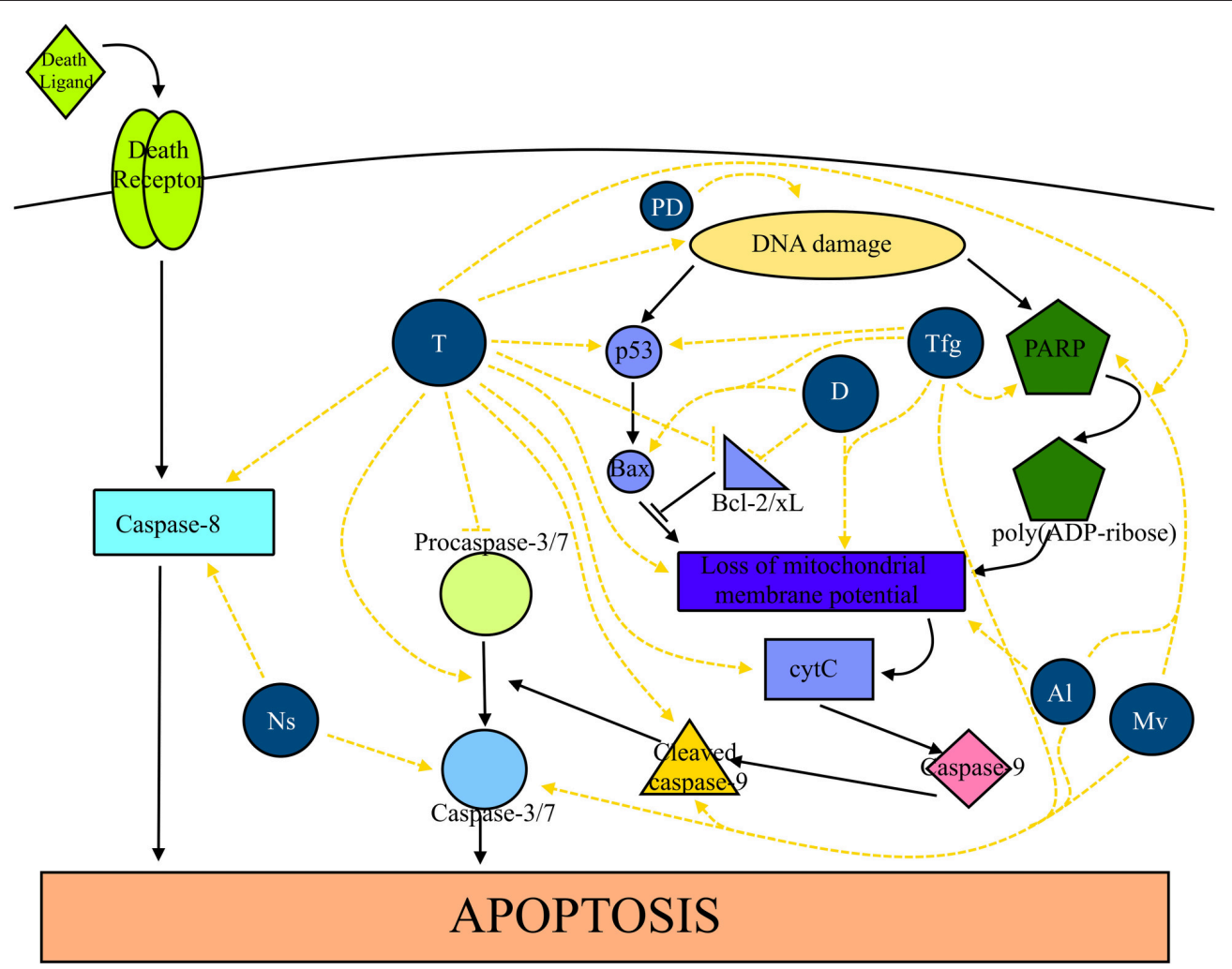

FIGURE 6 | Plants traditionally used in cancer therapy in North Africa as well as their compounds are able to induce apoptosis in several cancer types. Extracts from $N$. sativa (Ns) promote the activity of caspase-8, -3 , and -7 . Thymoquinone (T) enhances the activity of caspase-8, the conversion of procaspase-3 in caspase-3, the activation of caspase-9, Bax, cleavage of PARP, release of cytochrome c (cytC), loss of mitochondrial membrane potential and causes DNA damage. Furthermore, it inhibits the activity of procaspase-3, Bcl-2 and Bcl-xL. T. foenum-graecum (Tfg) exerts a stimulatory effect on caspase-3/7, p53, and Bax and causes the loss of mitochondrial membrane potential and DNA damage. Diosgenin (D) causes loss of mitochondrial membrane potential and blocks the activity of Bcl-2 and Bcl-xL. Protodioscin (PD) cause DNA damage. Extracts from A. longa (Al) and M. vulgare (Mv) causes the activation of caspase-3/7 and the cleavage of caspase-9.

decreased telomerase activity and caused disruption of telomeres length maintenance. These effects were more predominant in DNA-PKcs-normal glioblastoma cells (Gurung et al., 2010). Li et al. (2010) described caspase-3-dependent apoptosis in U266 multiple myeloma cells. According to Zubair et al. (2013), thymoquinone-induced cell death in prostate cancer cell lines was mediated through ROS-induced DNA damage since the effect was inhibited in the presence of a copper-chelating agent (neocuproine).

\section{Trigonella Foenum-Graecum and Diosgenin}

The treatment of several cancer cell lines (T-cell lymphoma, Bcell lymphoma, thyroid papillary carcinoma, and breast cancer) with an aqueous extract from the seeds of fenugreek induced apoptosis, if compared to the control (Alsemari et al., 2014). Similarly, a crude methanol extract triggered apoptosis by activating caspase- 3 and up-regulated the expression of p53 and PCNA in HepG2 cells (Khalil et al., 2015). Furthermore, the expression of Bax and the cleavage of PARP were also increased. In DU-123 cancer cells, fenugreek downregulated the expression of mutant p53 (Shabbeer et al., 2009). On the other hand, the extract inhibited the phosphorylation of EGFR in PC-3 cancer cells. A methanol extract of the whole plant induced apoptosis in MCF-7 cells (46.1 and 58.9\% apoptotic cells after 24 and 48 h, respectively; Alshatwi et al., 2013). Furthermore, it increased the expression of apoptotic genes, 0.9 -fold increase in caspase3, 0.25-fold in caspase-8, 0.3-fold in caspase-9, 1.7-fold in p53, 8.8-fold in fas, 0.12-fold in FADD, 0.4-fold in bax and 0.7-fold in bak. These results show that fenugreek induced apoptosis via a fas-dependent pathway, however, independent of FADD, Bax and Bak. A chloroform extract induces apoptosis in MCF-7 cells in a dose- and time-dependent manner $(23.2 \%$ and $73.8 \%$ apoptotic cells after 24 and $48 \mathrm{~h}$, respectively, with $50 \mu \mathrm{g} / \mathrm{mL}$; Khoja et al., 2011). Treating MCF-7 cells with an ethanolic extract induced apoptosis as observed by the flipping of phosphatidylserine from the inner to the outer phospholipid bilayer, loss of mitochondrial membrane potential, and DNA fragmentation (Sebastian and Thampan, 2007). In addition, the treatment increased the expression of apoptotic genes several folds, e.g., caspase-3 (3.5fold), caspase-8 (5.5-fold), caspase-9 (3.7-fold), p53 (1.4-fold), fas (1.7-fold), FADD (2.6-fold), bax (3.2-fold), and bak (4.4-fold). Treatment of Jurkat leukemia cells with an ethanolic extract induced the formation of vacuoles followed by cell membrane disintegration with a concomitant increase of LC-3 expression, all of which are signals of autophagic cell death (Al-Daghri et al., 2012). The treatment of DMBA-TPA-induced tumors in mice 
with a methanol extract of fenugreek decreased the number of PCNA-positive nuclei and increased the expression of p53 (Ali et al., 2014).

Diosgenin induced apoptosis in HT-29 colon cancer cells by decreasing Bcl-2 expression, while increasing the expression of caspase-3 (Raju et al., 2004). It induced apoptotic cell death as found by morphological and histological changes as well as chromatin condensation in squamous cell carcinomas. In addition, it decreased procaspase-3 levels, decreased Bcl-2 levels, increased Bax levels and inhibited the phosphorylation of JNK and Akt (Das et al., 2012). In A549 lung cancer cells, diosgenin decreased the mRNA levels of hTERT (Rahmati-Yamchi et al., 2014). This saponin disrupted mitochondrial membrane potential as well as the intracellular calcium concentration (578 vs. $210 \mathrm{nM}$ after 12 h; Leger et al., 2004). Furthermore, it increased the $\mathrm{Bax} / \mathrm{Bcl}-2$ ratio, caused PARP cleavage with concomitant DNA fragmentation. The increase in intracellular calcium caused a translocation to the membrane and subsequent cPLA 2 activation. In K562 leukemia cells, it also increased the intracellular calcium concentrations, hyperpolarization of mitochondrial membranes after $24 \mathrm{~h}$ followed by depolarization after 48 h (Liu et al., 2005). In addition, it activated caspase-3, but decreased the expression of $\mathrm{Bcl}-2$ and $\mathrm{Bcl}-\mathrm{xL}$ and increased Bax expression. Diosgenin induced apoptosis with an increase in hsp70 mRNA expression and in Bax/Bcl-2 ratio (Moalic et al., 2001).

Protodioscin induced apoptosis in HL-60 leukemic cells with typical morphological changes associated with apoptosis (increased numbers of apoptotic bodies, number of cells in the hypodiploid phase and DNA fragmentation; Hibasami et al., 2003).

\section{Aristolochia Longa}

The treatment of BL41 Burkitt's lymphoma with an aqueous extract from the roots induced apoptosis (20.7 vs. 2.7\%; Benarba et al., 2012) with concomitant mitochondrial membrane potential loss (53 vs. 11.6\%). Furthermore, it activated caspases-3 and -9 followed by PARP cleavage without affecting the activity of caspase-8. This suggests that $A$. longa activated the intrinsic pathway of apoptosis.

\section{Marrubium Vulgare}

Treating B16 and U251 cells with an ethanolic extract of $M$. vulgare cause increased fractions of both early and late apoptotic cells (Paunovic et al., 2016). In addition, it activated caspases-9 and -3 with concomitant PARP cleavage. A loss of mitochondrial membrane potential was also observed in both cell lines.

\section{Signal Transduction Pathways}

The cellular metabolism is tightly controlled by several pathways. In cancer cells, some of those pathways are dysregulated. NF$\kappa \mathrm{B}$ has been associated with the regulation of several processes such as inflammation, cell growth, and apoptosis (Ghosh and Dass, 2016). This nuclear transcription factor also controls several other biological pathways such as the MAPK or PI3K/Akt pathways. The activation of NF- $\mathrm{B}$ is associated with increased expression of several genes whose products are associated with tumorigenesis, such as antiapoptotic proteins (e.g., survivin, Bcl2), COX-2, matrix metalloproteinase-9, iNOS, and cell cycle regulation proteins (e.g., cyclin D1; Shishodia and Aggarwal, 2006). Another dysregulated pathway is STAT3. This signal transduction pathway has been associated with cell proliferation, cell survival and angiogenesis (Aggarwal et al., 2009; Becker et al., 2014; Yamamoto et al., 2014). STAT3 is activated by several intrinsic and extrinsic factors such as IL-6, JAKs, ERK, cigarette smoke (Aggarwal et al., 2009). In normal cells, this pathway is only transiently activated and tightly regulated. However, it is constitutively activated in cancer cells (Kortylewski et al., 2005). While NF- $\mathrm{B}$ and STAT3 pathways are activated in cancer cells, PPAR pathway is inactivated, because this pathway negatively controls proliferation and survival (Reka et al., 2011). Furthermore, PPAR inhibits NF-кB and STAT3 pathways. In addition, this pathway is also associated with cell cycle arrest and apoptosis induction (Dicitore et al., 2014). The effects of the extracts and major compounds (thymoquinone and diosgenin) on signal transduction pathways are represented in Figure 7.

\section{Nigella sativa and Thymoquinone}

Seed oil obtained from non-heated seeds of $N$. sativa inhibited $\mathrm{NF}-\kappa \mathrm{B}$ activity by around $50 \%$ while heating the seeds to $50^{\circ} \mathrm{C}$ caused a total inhibition of NF- $\kappa \mathrm{B}$ in MC38 colon carcinoma cell line (Agbaria et al., 2015). The major compound of black cumin, thymoquinone, acts on several signal transduction pathways, such as PPAR- $\gamma$ and STAT3. In fact, thymoquinone induced the expression of PPAR- $\beta / \delta$ (unspecifically) and PPAR- $\gamma$ (specifically) without significant effect on PPAR- $\alpha$ in MCF7 cells. The increase of PPAR- $\gamma$ activity was dose- and time-dependent (Woo et al., 2011). Furthermore, thymoquinone inhibited the activation of PI3K/Akt signaling pathway, decreased the phosphorylation of the PTEN and PDK1, the expression of phospho-GSK-3 $\beta$ and Bad, increased cleavage of caspase-9, increased the activity of GSK-3 3 , Bad and caspase- 9 and downregulated the expression of Akt downstream of the mTOR-dependent translational machinery (Rajput et al., 2013). In addition, in a doxorubicin-resistant MCF-7/Dox cell line, thymoquinone caused PARP cleavage with concomitant PTEN upregulation and increase of downstream proteins (Arafa et al., 2011). In p53-defective Jurkat lymphoblastic leukemia cells, the treatment increased both p73 $\alpha$ and $\beta$ expression, while decreasing the expression of UHRF1, DNMT1 and HDAC1 in a dose-dependent manner. In HCT116 cells, it decreased the phosphorylation of STAT3, the nuclear localization of p-STAT3 and the expression of STAT3 target genes related to survival (e.g., survivin and cyclin-D1 and-D2), while increasing the expression of cell cycle regulatory proteins (e.g., p27). Furthermore, thymoquinone inactivated kinases responsible for the phosphorylation of STAT3, EGFR tyrosine kinase, JAK2 and Src (Kundu et al., 2014). The compound also modulated the STAT3 pathway in U266 multiple myeloma cells. Thymoquinone inhibited the phosphorylation of constitutively expressed STAT3 and depleted the nuclear translocation of STAT3 without neither 


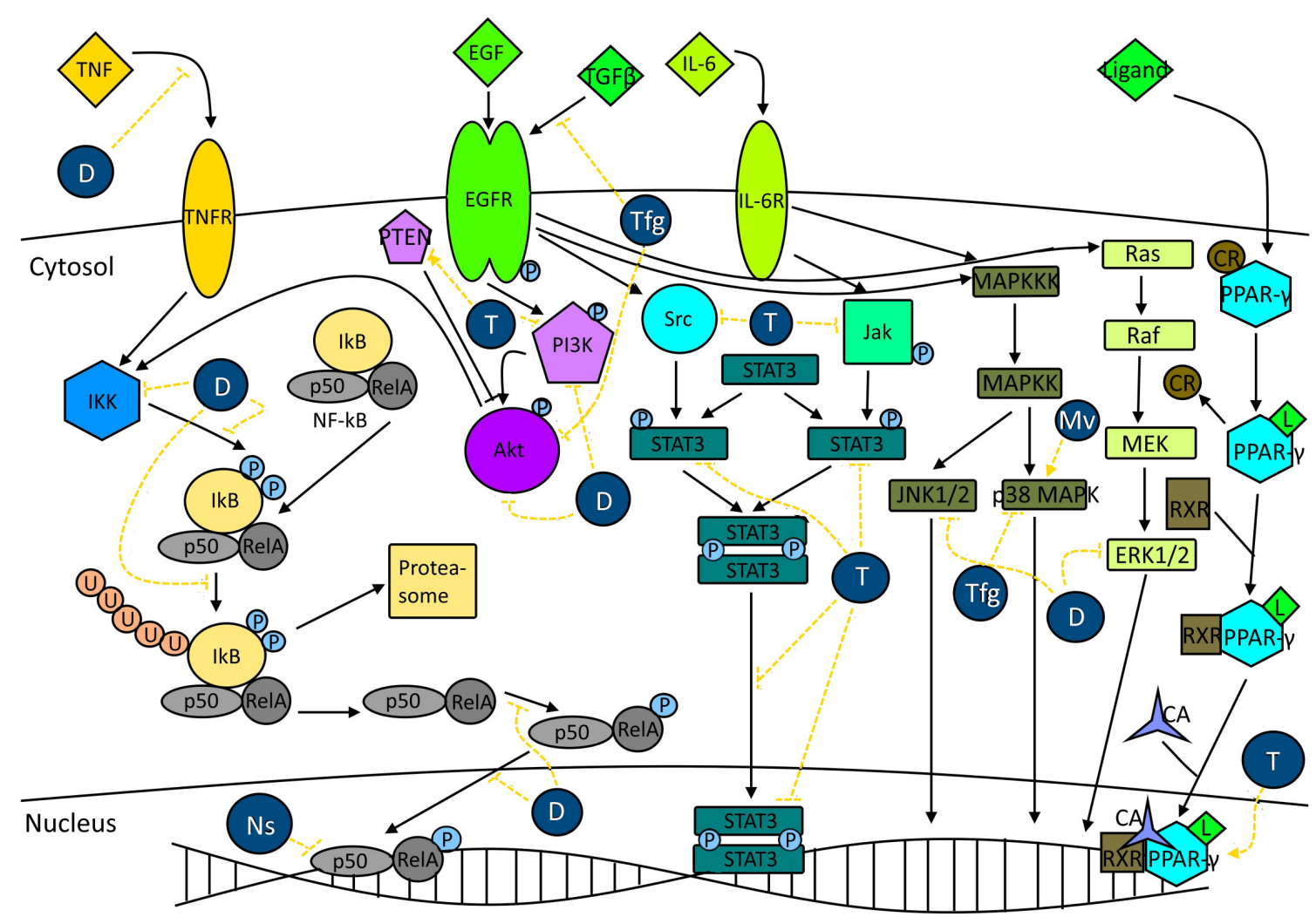

FIGURE 7 | Plants from the North Africa and major compounds are able to modulate signal transduction pathways associated with cancer survival. N. sativa extracts (Nv) are able to decrease NF-кB activity. The major compound, thymoquinone (T) decreases STAT3 phosphorylation, nuclear translocation and STAT3-induced gene expression. Furthermore, it inhibits or activates the activity of PTEN, inhibits the phosphorylation of PI3K and promotes the activity of PPAR- $\gamma$. Extracts from $T$. foenum graecum (Tfg) exert an inhibitory effect on the phosphorylation of EGFR induced by TGF $\beta$ as well as Akt phosphorylation. In addition, it decreases the activity of p38 MAPK. Diosgenin (D) inhibits NF-kB activity induced by TNF, inhibits IKK (IkB $\alpha$ kinase) activity and decreases phosphorylation and degradation of IkB $\alpha$. Furthermore, it decreases the phosphorylation and nuclear translocation of p65 (RelA). In addition, it inhibits the phosphorylation of PI3K, Akt, ERK1/2, and JNK1/2. Extracts from M. vulgare (Mv) exert a stimulatory effect on p38 MAPK activity. CR, Co-repressor; CA, Co-activator.

affecting protein levels of STAT3 nor the phosphorylation and protein levels of STAT5 (Li et al., 2010). Furthermore, thymoquinone suppressed IL-6-induced phosphorylation of STAT3, activation of Akt and the expression of STAT3dependent genes. In addition, it inhibited the phosphorylation of constitutively expressed JAK2 and of activated protein tyrosine phosphatases and it induced the expression of SH-PTP2, which negatively regulates STAT3 activation. Finally, thymoquinone downregulated the expression of STAT3dependent genes associated with cell survival, proliferation and angiogenesis.

\section{Trigonella Foenum-Graecum and Diosgenin}

A fenugreek extract decreased the phosphorylation of EGFR induced by TGF $\beta$ in PC-3 cancer cells (Shabbeer et al., 2009). Furthermore, it inhibited the TGF $\beta$-induced Akt phosphorylation and induced p21 expression. In an animal model of skin carcinogenesis induced by DMBA-TPA, a methanol extract decreased p38MAPK expression (Ali et al., 2014). Diosgenin inhibited TNF-induced expression of NF$\kappa \mathrm{B}$ on KBM-5 cells in a dose- and time-dependent manner
(Shishodia and Aggarwal, 2006). Furthermore, it decreased the degradation and phosphorylation of IкB $\alpha$ and the activation of Ік $\mathrm{B} \alpha$ kinase. In addition, it inhibited the phosphorylation and subsequent p65 nuclear translocation and activation of the Akt pathway. Concomitantly, the saponin inhibited the expression of NF-кB-dependent genes, e.g., antiapoptotic genes, MMP-9 and cyclin-D1. These effects were found both in ER-positive and ER-negative cells, thus suggesting that NF- $\kappa$ B inhibition was ERindependent. Diosgenin inhibited the phosphorylation of PI3K, Akt, ERK1/2, JNK1/2 in a dose- and time-dependent manner (Chen et al., 2011). Furthermore, NF-кB nuclear translocation was inhibited in the presence of diosgenin. Diosgenin treatment activated NF-кB in 1547 osteosarcoma cells (Moalic et al., 2001).

\section{Marrubium Vulgare}

Paunovic et al. (2016) described the activation of p38 MAPK with concomitant activation of proapoptotic genes and cell cycle inhibitor and inhibition of antiapoptotic genes after treatment with an ethanolic extract. Furthermore, it conversed LC3-I to the LC3-II in both B16 and U251 cell lines with associated upregulation of autophagy-associated genes. 


\section{Invasiveness, Migration, and Metastasis}

Cancer cell invasion is one of the major challenges to achieve relapse-free and sustainable patient survival (Alexander and Friedl, 2012). Tumor invasion is characterized by cell motility, migration and degradation of the extracellular matrix (Domoto et al., 2016) with concomitant intravasation into blood and/or lymphatic vessels and metastasis of distant organs (Alexander and Friedl, 2012). Although, only very few migrant cells initiate de novo tumor growth in a new organ (Oh et al., 2015), metastasis is responsible for most of the cancer-related deaths. Invasion is regulated by several factors (Alexander and Friedl, 2012), such as the PTEN/PI3K and MAPK/ERK pathways as well as increased MMP expression and activity. The effect of the extracts and major compounds on the major metalloproteinases associated with cancer invasiveness can be found in Figure 8.

\section{Nigella Sativa and Thymoquinone}

A supercritical carbon dioxide extract inhibited colony formation in a dose-dependent manner, decreased cell motility $(63.22 \%$ inhibition at $40 \mu \mathrm{g} / \mathrm{mL}$ ) and cell invasion (79.29\% inhibition at $40 \mu \mathrm{g} / \mathrm{mL}$; Baharetha et al., 2013). Thymoquinone inhibited migration of both MCF-7 and MDA-MB-231 cells and invasion of MDA-MB-231 cells (Woo et al., 2011).

\section{Diosgenin and Trigonelline}

To the best of our knowledge, no studies assessing the antiinvasiveness and anti-migration capacities of whole extracts from T. foenum-graecum have been carried out as of yet. Therefore, we only focus on results related to diosgenin. Treatment with diosgenin inhibited TNF-induced invasion in H1299 cells by $50 \%$ and $\sim 40 \%$, respectively, prior and after invasion induction (Shishodia and Aggarwal, 2006). Non-cytotoxic doses decreased the migration of PC-3 cells in a time-dependent manner as well as the cell invasion in a dose-dependent manner (22 and $40 \%$ invasion inhibition at 10 and $20 \mu \mathrm{M}$, respectively; Chen et al., 2011). Furthermore, the saponin decreased MMP2 and MMP-9 activity with concomitant suppression of the mRNA and protein expression. In addition, it also decreased the mRNA levels of MMP-7 and EMMPRIN (extracellular

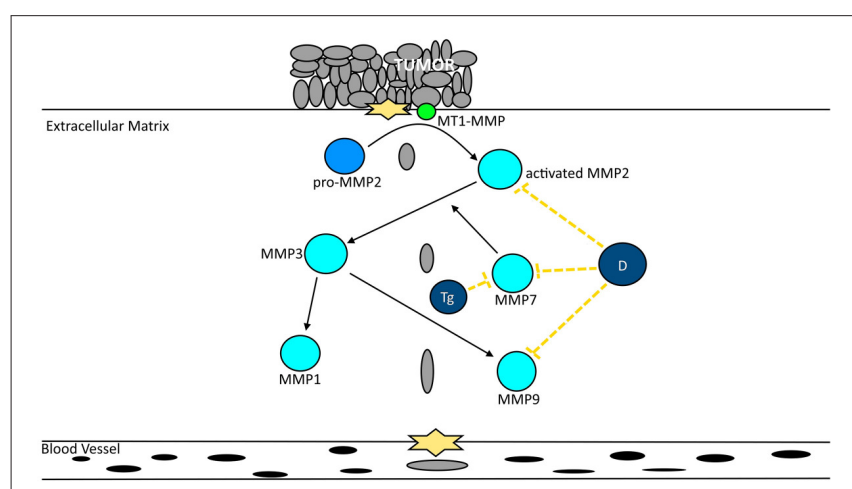

FIGURE 8 | Extracts from North African plants and major compounds decrease cancer migration by inactivating metalloproteinases. Diosgenin (D) decreases the activity of MMP-2, -7, and 9. Trigonelline (Tg) decreases the activity of MMP-7. inducer of matrix metalloproteinase), while increasing the levels of TIMP-2 (tissue inhibitor of metalloproteinase-2). Tube formation in HUVECs induced by conditioned medium by PC3 cells was inhibited suggesting that diosgenin might inhibit angiogenesis.

Trigonelline (Figure 4, 4), the major alkaloid of fenugreek has been described to act in an anticarcinogenic manner (El Bairi et al., 2017). In fact, Hirakawa et al. (2005) demonstrated that the ROS-induced migration of AH109A hepatoma cells was inhibited in a dose-dependent manner by this alkaloid. Furthermore, this compound decreased the motility of Hep3B (Liao et al., 2015) as well as the expression of MMP-7, the expression of phospho-Nrf2, PKC $\alpha$, ERK1/2, and p38, while increasing the phosphorylation of Raf on serine-259. In addition, trigonelline decreased the expression and activity of several anti-oxidative enzymes.

\section{TOXICOLOGICAL EVIDENCE}

Toxicity testing represents an important step in the drug development process evaluating the potential of a medicinal plant, before it can be further considered for clinical trials.

\section{Nigella Sativa and Thymoquinone}

Black cumin is widely used in traditional medicine. However, it is commonly used in low doses due to the lack of scientific evidence regarding its toxicity (Al-Ali et al., 2008; Dollah et al., 2013). Nevertheless, some authors described toxic effects of $N$. sativa both in vitro and in vivo. In fact, Khader et al. (2007) described that $0.3 \mathrm{mg} / \mathrm{mL}$ of a seed extract from $N$. sativa exerted genotoxicity since it promoted the formation of MNNG-induced chromosomal aberrations and the appearance of micronuclei. The same authors described that thymoquinone $(20 \mu \mathrm{M})$ decreased cell proliferation, while necrosis was augmented at concentrations as low as $2.5 \mu \mathrm{M}$. Higher concentrations exerted acute cytotoxicity (Khader et al., 2009). Regarding the genotoxicity of thymoquinone, the number of chromosomal aberrations and micronuclei increased in a dose-dependent manner up to $10 \mu \mathrm{M}$. In vitro assays are of limited predictive power regarding potential toxicity in human subjects due to the fact that cell cultures do not reflect the biotransformation that occurs in vivo (Reichling et al., 2009). The $\mathrm{LD}_{50}$ of a fixed oil from the seeds of $N$. sativa was determined for its acute and chronic toxicity (Zaoui et al., 2002). For acute toxicity, the $\mathrm{LD}_{50}$ was 28.8 and $2.06 \mathrm{~mL} / \mathrm{kg}$ body weight of mice for oral and intraperitoneal administration, respectively. The $\mathrm{LD}_{50}$ of an alcoholic extract administered intraperitoneally was $561 \mathrm{mg} / \mathrm{kg}$ (Paarakh, 2010). The acute toxicity of thymoquinone, the major constituent of N. sativa, was determined by Badary et al. (1998). The $\mathrm{LD}_{50}$ was $2.4 \mathrm{~g} / \mathrm{kg}$. High doses of thymoquinone induced hypoactivity and breathing difficulties before death. After 24 $\mathrm{h}$ of treatment, high doses of thymoquinone decreased liver, plasma and heart GSH levels. Furthermore, the activities of ALP, LDH and CPK, and plasma concentration of urea and creatinine were elevated. The chronic toxicity was determined in rats by giving $2 \mathrm{~mL} /$ body weigh/day for 12 weeks (Zaoui et al., 2002). At the end of the treatment, no differences in 
key enzymes were detected, serum cholesterol, triglycerides, and glucose significantly decreased. Furthermore, the counts for leukocytes and platelets decreased while hematocrit and hemoglobin increased. The treated groups presented a lower body weight at 6 weeks and onwards, whereas the organ weight remained unchanged. The subchronic administration of 30$90 \mathrm{mg} / \mathrm{kg} /$ day thymoquinone for 90 days showed no effect on key enzymes, body weight, hematological parameters nor did it cause histopathological changes (Badary et al., 1998). The oral administration of aqueous, methanol and chloroform extracts exerted no mortality 7 days post-treatment. However, at $21 \mathrm{~g} / \mathrm{kg}$ of aqueous and chloroform extracts lowered the body weight (Vahdati-Mashhadian et al., 2005). The subacute effects of these extracts were determined by giving orally $2 \mathrm{~g} / \mathrm{kg} /$ day for 14 days. At the end of the treatment, the aqueous extract decreased alkaline phosphatase (ALP), if compared to the control. Other enzymes were not affected. The chloroform extract decreased the activity of all tested enzymes. The oral intake of either fixed oil or essential oil was considered as safe, since no changes on serological indexes and white and red cell count appeared even 56 days after treatment (Tauseef Sultan et al., 2009). AlAli et al. (2008) demonstrated that the toxicity of $N$. sativa depends on the type of administration. Intraperitoneal injections to mice and rats demonstrated low $\mathrm{LD}_{50}$ values (104.7 and $57.5 \mathrm{mg} / \mathrm{kg}$ for mice and rats, respectively), whereas upon oral administration the lethal doses were 870.9 and $794.3 \mathrm{mg} / \mathrm{kg}$, respectively. Furthermore, the intraperitoneal administration led to abdominal muscle contraction and ataxia, which persisted for a couple of hours. After $6 \mathrm{~h}$, the animals were drowsy and less responsive. For the oral administration, the drowsiness and poor responsiveness was more gradual and lasted until the animal's death or vanished after $24 \mathrm{~h}$. The oral administration of grounded seeds to rats in doses of $0.01,0.10$, and $1.00 \mathrm{~g} / \mathrm{kg}$ body weight for 5 weeks caused no changes in urea and creatinine levels, neither did it cause histopathological changes in the kidney (Dollah et al., 2013). In addition to both in vitro and in vivo studies, several clinical trials have been conducted using either $N$. sativa and thymoquinone without demonstrating any severe side effects (Qidwai et al., 2009; Akhondian et al., 2011; Amin et al., 2015; Mohtashami et al., 2015). In addition to the rather safe toxicological profile, i.p. pre-treatment with $12.5 \mathrm{mg} / \mathrm{kg}$. of $N$. sativa volatile oil decreased the hepatotoxicity induced by $\mathrm{CCl}_{4}$ by decreasing the level of serum enzymes and MDA content (Mansour et al., 2001). On the other hand, thymoquinone decreased cisplatin-induced nephrotoxicity by lowering urea and creatinine levels and improvement of polyuria, kidney weight, and creatinine clearance (Badary et al., 1997).

\section{Trigonella Foenum-Graecum and Diosgenin}

Fenugreek has been widely used in traditional medicine for treating several ailments and diseases, although several sideeffects have been reported (Al-Ashban et al., 2010), including anti-fertility and abortifacient effects (Ouzir et al., 2016). The lethal dose of an alcoholic extract of fenugreek seed was above 1 g/kg i.p. (Sur et al., 2001). The intraperitoneal administration of an aqueous extract yielded an $\mathrm{LD}_{50}$ close to $4,000 \mathrm{mg} / \mathrm{kg}$ (Javan et al., 1997). The $\mathrm{LD}_{50}$ upon i.p. administration of an aqueous extract from the leaves of $T$. foenum-graecum was $1.9 \mathrm{~g} / \mathrm{kg}$, while the $\mathrm{LD}_{50}$ increased to $10 \mathrm{~g} / \mathrm{kg}$ upon oral administration (Abdel-Barry et al., 1997). The i.p. administration of a glycoside extract from fenugreek revealed an $\mathrm{LD}_{50}$ of $0.65 \mathrm{~g} / \mathrm{kg}$, while the $\mathrm{LD}_{50}$ value increased to $7 \mathrm{~g} / \mathrm{kg}$ upon oral administration (AbdelBarry and Al-Hakiem, 2000). A fenugreek extract enriched in furostanolic saponins $(>60 \% \mathrm{w} / \mathrm{w})$ did neither show acute toxicity $\left(\mathrm{LD}_{50}>5,000 \mathrm{mg} / \mathrm{kg}\right.$ ) nor sub-chronic toxicity (Swaroop et al., 2014). Supplementation with $100 \mathrm{mg} / \mathrm{kg} /$ day in drinking water for 3 months did not show alarming signs of chronic or acute toxicity (Al-Ashban et al., 2010). Similarly, intragastrical administration of fenugreek extract did not exert acute toxicity upon oral supplementation (Muralidhara et al., 1999). Although, several studies have demonstrated low toxicity of fenugreek extracts, some authors have established that these extracts are toxic to the fetus development (Khalki et al., 2010; Mozaffari et al., 2010). Furthermore, Khader et al. (2007) also described the mutagenic potential of T. foenum-graecum. Several clinical trials have been conducted using fenugreek, which described mostly non-serious side effects. In fact, the supplementation of diabetic individuals with $25 \mathrm{~g} /$ day for 24 weeks revealed a few side effects (diarrhea and excess flatulence) that subdued after a few days (Sharma et al., 1996). In a single-blind trial, 20 healthy men treated with an aqueous extract minimal side effects were observed (feeling of hunger, dizziness and frequency of micturition; Abdel-Barry et al., 1997). A double-blind, randomized and placebo-controlled 6-week trial in 60 healthy adult males showed no adverse side effects using a standardized fenugreek extract, except for three individuals that complained about slight stomach discomfort after taking the extract in the absence of food (Steels et al., 2011). In another double-blind, randomized, placebo-controlled three-period cross-over trial, 25 healthy male individuals were supplemented with fenugreek for three 14-day treatment period with a 14-day washout period, only few side effects were described (abdominal pain and urine smell; Chevassus et al., 2009). In a double-blind and placebocontrolled, Gupta et al. (2001) described that treatment with 1 $\mathrm{mg} /$ day of a hydroalcoholic seed extract for 2 months caused dyspepsia and mild abdominal distension without affecting the kidney and liver. A double-blind, randomized and placebocontrolled trial on 120 healthy adult male using a standardized seed extract showed no adverse effects during 12 weeks of treatment (Rao et al., 2016). Some minor side effects were observed that were dispersed between both treatment and control groups. Thus, they cannot be associated with fenugreek consumption. Swaroop et al. (2015) conducted an open label, one-arm, non-randomized, and post-marketing surveillance in 50 premenopausal women and did not find hepatotoxicity, nephrotoxicity and cardiotoxicity during the 90 days observation period. Furthermore, changes in the hemogram and total leukocyte count were not observed, although the hemoglobin levels slightly increased. A short-term, single site, double-blind, randomized and placebo-controlled study was carried out in 80 women, who consumed $600 \mathrm{mg} /$ day of a standardized seed extract (Rao et al., 2015). No major adverse effects were observed 
with only two patients manifesting minor side effects in the treatment group.

\section{Aristolochia Longa}

Although beneficial effects of $A$. longa were reported not only against cancer, but also against several other ailments, this plant is rich in aristolochic acids (Cherif et al., 2014). These acids are responsible for the toxicity associated with many species of the Aristolochia genus (Yamani et al., 2015) and cause a syndrome named aristolochic acid nephropathy (Benzakour et al., 2012; Cherif et al., 2014). By contrast, several studies have assessed that extracts from the roots of $A$. longa to be safe in a single dose treatment (Benzakour et al., 2011; Benarba et al., 2012, 2016; Cherif et al., 2014). On the other hand, Cherif et al. (2014) described 1/6 mortality upon application of $4 \mathrm{~g} / \mathrm{kg}$ and $2 / 6$ mortality upon $5 \mathrm{~g} / \mathrm{kg}$. Low doses failed to exhibit sings of sub-chronic toxicity (Benzakour et al., 2011; Cherif et al., 2014). By contrast, high doses demonstrated serious toxicity, such as atypical locomotion, anorexia, asthenia, ataxia, diarrhea, and urination (Benzakour et al., 2011; Cherif et al., 2014).

\section{SCIENTIFIC EVIDENCE ON MEDICINAL PLANTS NOT TRADITIONALLY USED FOR CANCER TREATMENT}

Several plants are widely used as by herbalists in North Africa to treat diseases other than cancer. Nevertheless, several studies have been conducted on some of those plants highlighting their potential as anticancer agents. Therefore, we also report on these medicinal plants. Diethyl ether and petroleum ether extracts from Alhagi maurorum demonstrated a comparable cytotoxicity toward several cancer lines, including $\mathrm{C} 32$ cells as the most susceptible to the first extract $\left(\mathrm{IC}_{50}=2.7 \mu \mathrm{g} / \mathrm{mL}\right.$ ) and HeLa cells as the most susceptible to the latter $\left(\mathrm{IC}_{50}=40.1 \mu \mathrm{g} / \mathrm{mL}\right.$; Loizzo et al., 2014). Methanolic extracts from Artemisia herbaalba, Ruta chalepensis, and Peganum harmala all demonstrated cytotoxic effects in a dose-dependent manner (Khlifi et al., 2013). An ethyl acetate extract of Argania spinosa inhibited the growth of MCF-7 cells (IC $50=42 \mu \mathrm{g} / \mathrm{mL}$; El Babili et al., 2010). Extracts of Inula viscosa were cytotoxic toward several cancer cell lines, including multidrug-resistant lines, with the hexane extract demonstrating the most promising activity $\left(\mathrm{IC}_{50}=9.56-15.67\right.$ $\mu \mathrm{g} / \mathrm{mL}$; Merghoub et al., 2016). In a comparative study with 16 plants, the methanol extracts from I. viscosa and Ononis hirta were the most potent ones against all tested cancer cell lines. For instance, in MCF7 cells the $\mathrm{IC}_{50}$ values were in a range from 15.78 to $27.96 \mu \mathrm{g} / \mathrm{mL}$ (Talib and Mahasneh, 2010). A crude alkaloid extract from Glaucium flavum inhibited the growth of several human cancer cell lines in a dose dependent manner $\left(\mathrm{IC}_{50}\right.$ $=7.9-13.6 \mu \mathrm{g} / \mathrm{mL}$; Bournine et al., 2013a). Furthermore, this type of extract significantly inhibited the growth of MDA-MB231 cells in a dose-dependent manner (Bournine et al., 2013b). Treating mice bearing Ehrlich ascites tumor with an methanolic extract of Calligonum comosum decreased the number of viable cells $\left(99.2 \times 10^{6}\right.$ vs. $192.8 \times 10^{6}$; Badria et al., 2007). In another study, a methanolic extract of C. comosum inhibited the viability of HepG2 carcinoma cells in a dose-dependent manner $\left(\mathrm{IC}_{50}=9.60 \mu \mathrm{g} / \mathrm{mL}\right.$; Shalabi et al., 2015). Similarly, Aloe vera also decreased cell viability of HepG2 in a dose-dependent manner $\left(\mathrm{IC}_{50}=10.45 \mu \mathrm{g} / \mathrm{mL}\right)$. The aqueous extract obtained from garlic (Allium sativum) decreased the viability of murine CT26. WT colon carcinoma cells (Lee et al., 2013). Several extracts from mulberry (Morus alba) decreased the viability of HepG2 in a time-dependent manner (Fathy et al., 2013). The essential oil of Artemisia campestris inhibited the growth of HT29 cells $\left(\mathrm{IC}_{50}=46.82 \mu \mathrm{g} / \mathrm{mL}\right.$; Akrout et al., 2011). Several extracts of Thymelaea hirsuta only weakly inhibited cell growth at high concentrations of $100 \mu \mathrm{g} / \mathrm{mL}$ (58.19-65.54\% inhibition). Several roots extracts from Linum usitatissimum significantly inhibited the growth of Jeg3 trophoblast tumor cells (Abarzua et al., 2007). Infusions from Mentha spp., Rosmarinus officinalis and Origanum majorana inhibited the growth of several cancer cell lines, including HeLa, Jurkat and MCF-7 (Elansary and Mahmoud, 2015). Seed oil isolated from Ecbalium elaterium inhibited the growth of HT-29 colonic adenocarcinoma $\left(\mathrm{IC}_{50}=\right.$ $4.86 \mu \mathrm{g} / \mathrm{mL}$ ) and HT-1080 colonic fibrosarcoma cells $\left(\mathrm{IC}_{50}=\right.$ $4.16 \mu \mathrm{g} / \mathrm{mL}$; Touihri et al., 2015). Treating MCF-7 and OVCAR cells with $50 \mathrm{mg} / \mathrm{L}$ of hydromethanolic extract from the flower buds of Cistus salviifolius inhibited the growth by 35.16 and 36.85\%, respectively (El Euch et al., 2015). The methanolic extract of Achillea odorata $(50 \mu \mathrm{g} / \mathrm{mL})$ inhibited the MCF7 cell growth of MCF-7, Hep2 and WEHI cancer cells in a dosedependent manner with $42.90,61.54$, and $81.13 \%$ inhibition, respectively (Boutennoun et al., 2017). The growth of B16F10 was inhibited in a dose- and time-dependent manner $\left(\mathrm{IC}_{50}\right.$ $\sim 736 \mu \mathrm{g} / \mathrm{mL}$ after $24 \mathrm{~h}$ and $\sim 650 \mu \mathrm{g} / \mathrm{mL}$ after $48 \mathrm{~h}$ ) after treatment with an aqueous extract from the gall of Limoniastrum guyonianum (Krifa et al., 2014). Furthermore, it also decreased both tumor weight and size in B16F10-bearing mice. In a similar study, the same type of extract exerted antiproliferative activity toward HeLa cells in a dose- and time-dependent manner $\left(\mathrm{IC}_{50}\right.$ $=170$ and $140 \mu \mathrm{g} / \mathrm{mL}$ after 24 and $48 \mathrm{~h}$, respectively; Krifa et al., 2013). A hexane extract from the bark of Ficus drupacea decreased the growth of several cancer lines with T24 cells as the most susceptible ones $\left(\mathrm{IC}_{50}=21.32 \mu \mathrm{g} / \mathrm{mL}\right.$; Yessoufou et al., 2015). The anticancer effects of a methanolic extract of Cleome arabica have been described against several cell lines. SK-N-BE neuroblastoma cells were the most sensitives ones to this extract (Tigrine et al., 2013). Saffron (Crocus sativus) exerted antiproliferative activity against two aggressive prostate cancer cell lines injected into mice by decreasing tumor weights (Festuccia et al., 2014). Furthermore, it decreased the metastatic capabilities of the tumors. In another study, saffron extracts inhibited the growth of both $\mathrm{p} 53^{+/+}$and $\mathrm{p} 53^{-/-}$HCT116 cell lines in a dose- and time-dependent manner (Bajbouj et al., 2012).

In a MNNG-induced gastric carcinogenesis model, treatment with an aqueous extract from $C$. sativus inhibited the progression to the adenoma stage in a dose-dependent manner (Bathaie et al., 2013). Saffron also inhibited the growth of A549 lung cancer cells in a dose- and time-dependent manner $\left(\mathrm{IC}_{50}\right.$ $=380$ and $170 \mu \mathrm{g} / \mathrm{mL}$ after 48 and $72 \mathrm{~h}$; Samarghandian 
et al., 2013). Dichloromethane and methanol extracts from Limonium densiflorum were cytotoxic against different cancer cell lines being the dichloromethane extract the most promising one (Medini et al., 2015). The ethyl acetate extract from Cyperus rotundus weakly inhibited the proliferation of $\mathrm{K} 562$ erythroleukemia cells ( $\mathrm{IC}_{50}=100 \mu \mathrm{g} / \mathrm{mL}$; Kilani-Jaziri et al., 2009). This type of extract only weakly inhibited the growth of L1210 cell line $\left(\mathrm{IC}_{50}=200 \mu \mathrm{g} / \mathrm{mL}\right.$ ), while a lyophilized infusion and a methanol extract exerted negligible activity (Kilani et al., 2008). Several extracts from the leaves of Punica granatum were screened for their antiproliferative effects toward MCF7 cells (Bekir et al., 2013). The methanol extract was the most effective $\left(\mathrm{IC}_{50}=31 \mathrm{mg} / \mathrm{L}\right)$. A hydroethanolic extract from the grains of Echinochloa crus-galli demonstrated potent cytotoxicity against several cancer cell lines (El Molla et al., 2016). Extracts from Ceratonia siliqua and Quercus ilex inhibited the proliferation of U87 glioblastoma in a dose-dependent manner (Amessis-Ouchemoukh et al., 2017). The growth of $\mathrm{KB}$ cancer cell line was inhibited in a dose-dependent manner by an aqueous extract from Moringa oleifera leaves (Sreelatha et al., 2011). Several extraction techniques from the leaves of various olive cultivars inhibited the growth of the JIMT-1 breast cancer cell line in a dose-dependent manner (Taamalli et al., 2012). An aqueous extract from Jatropha podagrica strongly inhibited the growth of both PC12 and A549 in a dose-dependent manner (Ghali et al., 2013). Henna (Lawsonia inermis) at doses of $180 \mathrm{mg} / \mathrm{kg}$ for 15 days significantly reduced the growth of Dalton's lymphoma ascites-bearing mice (Priya et al., 2011). Treating Ehrlich ascites carcinoma-bearing mice with henna extract decreased the number of cancer cells (Ozaslan et al., 2009). Similarly, the chloroform extract of L. inermis was very cytotoxic toward HepG2 $\left(\mathrm{IC}_{50}=0.3\right.$ $\mu \mathrm{g} / \mathrm{mL})$ and MCF-7 ( $\mathrm{IC}_{50}=24.8 \mu \mathrm{g} / \mathrm{mL}$; Endrini et al., 2002, 2007). Ethyl acetate and petroleum ether extracts both decreased viability of MCF7 cells $\left(\mathrm{IC}_{50}=27\right.$ and $22 \mathrm{mg} / \mathrm{mL}$, respectively; El Babili, 2013). The essential oil of henna also showed potent cytotoxicity toward HepG2 $\left(\mathrm{IC}_{50}=24 \mu \mathrm{g} / \mathrm{mL}\right.$; Rahmat et al., 2006). An aqueous extract of Urginea maritima inhibited the growth of SH-SY5Y in a dose- and time-dependent manner $\left(\mathrm{IC}_{50}=10 \mu \mathrm{g} / \mathrm{mL}, 1 \mu \mathrm{g} / \mathrm{mL}\right.$ and $100 \mathrm{ng} / \mathrm{mL}$ after 24, 48, and $72 \mathrm{~h}$; Elghuol et al., 2016). Both aqueous and ethanol extracts from leaves, seeds and roots of Plectranthus amboinicus similarly inhibited the growth of two cancer cell lines, HepG2 and MCF-7 (El-hawary et al., 2012). Hexane, ethyl acetate and chloroform extracts from Aristolochia baetica significantly inhibited the growth of MCF-7 cells in a doseand time-dependent manner (Chaouki et al., 2010). Similarly, ethyl acetate and methanol extracts of Origanum compactum

\section{REFERENCES}

Abarzua, S., Szewczyk, M., Gailus, S., Richter, D. U., Ruth, W., Briese, V., et al. (2007). Effects of phytoestrogen extracts from Linum usitatissimum on the Jeg3 human trophoblast tumour cell line. Anticancer Res. 27, 2053-2058.

Abdel-Barry, J. A., Abdel-Hassan, I. A., and Al-Hakiem, M. H. (1997). Hypoglycaemic and antihyperglycaemic effects of Trigonella foenum-graecum both inhibited the proliferation in dose- and time-dependent manner.

\section{CONCLUSION}

The extensive research on the anticancer activity of plants from the North Africa highlighted their potential for future chemotherapeutic agents, especially plants from Morocco and Algeria, which have the most ethnobotanical references regarding the anticancer effects of plants. Amongst all the botanical families ascribed, Lamiaceae, Apiaceae, Compositae, and Fabaceae are the ones with more plants used in folk medicine. In fact, the most used plants, T. foenum-graecum, A. longa, M. vulgare, and $C$. absus belongs to these families. On the other hand, $N$. sativa (Ranunculaceae) is also extensively used as herbal anticancer drug in North African traditional medicine. The anticancer effects of $N$. sativa and T. foenum-graecum are widely described both in cytotoxic assays and in mechanisms underlying those effects. Although A. longa and M. vulgare are referred by herbalists for the treatment of cancer, very few studies assessing their anticancer properties have been conducted while studies demonstrating the anticancer effects of C. absus are yet to be conducted. The anticancer effect of these plants act on a panoply of cellular pathways being the induction of apoptosis and modulation of signal transduction pathways the most studied, while the ability to suppress invasiveness, migration and metastasis is poorly evaluated. Although, the safety profile of the plants has been described with minor side effects, T. foenumgraecum have been associated with anti-fertility and abortifacient effects and $A$. longa have been described as inducing severe side effects after chronic consumption of the plant. Despite the myriad of studies regarding the anticancer effect as well as extensive literature on the underlying mechanisms, very few in vivo studies have been conducted and clinical trials are still to be conducted.

In order to establish these plants as potential chemotherapeutic agents several points must be addressed namely the assessment of anticancer potential using in vivo models. Furthermore, clinical trials are still lacking, which limits the therapeutic application of these plants. In addition, a better understanding on the mechanisms of action is still needed in order to establish rational phytotherapeutic approaches.

\section{AUTHOR CONTRIBUTIONS}

JA analyzed the relevant literature, wrote the manuscript and prepared tables and figures. AR, TE reviewed the manuscript. LS supervised the work and review the manuscript.

leaf in normal and alloxan induced diabetic rats. J. Ethnopharmacol. 58, 149-155. doi: 10.1016/S0378-8741(97)00101-3

Abdel-Barry, J. A., and Al-Hakiem, M. H. (2000). Acute intraperitoneal and oral toxicity of the leaf glycosidic extract of Trigonella foenum-graecum in mice. J. Ethnopharmacol. 70, 65-68. doi: 10.1016/S0378-8741(99)00 109-9

Adeloye, D., David, R. A., Aderemi, A. V., Iseolorunkanmi, A., Oyedokun, A., Iweala, E. E., et al. (2016). An estimate of the incidence of prostate cancer 
in Africa: a systematic review and meta-analysis. PLoS ONE 11:e0153496. doi: 10.1371/journal.pone.0153496

Agbaria, R., Gabarin, A., Dahan, A., and Ben-Shabat, S. (2015). Anticancer activity of Nigella sativa (black seed) and its relationship with the thermal processing and quinone composition of the seed. Drug Des. Dev. Ther. 9, 3119-3124. doi: 10.2147/DDDT.S82938

Aggarwal, B. B., Kunnumakkara, A. B., Harikumar, K. B., Gupta, S. R., Tharakan, S. T., Koca, C., et al. (2009). Signal transducer and activator of transcription-3, inflammation, and cancer. Ann. N.Y. Acad. Sci. 1171, 59-76. doi: 10.1111/j.1749-6632.2009.04911.x

Ahmad, R., Ahmad, N., Naqvi, A. A., Shehzad, A., and Al-Ghamdi, M. S. (2016). Role of traditional Islamic and Arabic plants in cancer therapy. J. Tradit. Complement. Med. 7, 195-204. doi: 10.1016/j.jtcme.2016.05.002

Ait Mbarek, L., Ait Mouse, H., Elabbadi, N., Bensalah, M., Gamouh, A., Aboufatima, R., et al. (2007). Anti-tumor properties of blackseed (Nigella sativa L.) extracts. Braz. J. Med. Biol. Res. 40, 839-847. doi: 10.1590/S0100-879X2006005000108

Akhondian, J., Kianifar, H., Raoofziaee, M., Moayedpour, A., Toosi, M. B., and Khajedaluee, M. (2011). The effect of thymoquinone on intractable pediatric seizures (pilot study). Epilepsy Res. 93, 39-43. doi: 10.1016/j.eplepsyres.2010.10.010

Akrout, A., Gonzalez, L. A., El Jani, H., and Madrid, P. C. (2011). Antioxidant and antitumor activities of Artemisia campestris and Thymelaea hirsuta from southern Tunisia. Food Chem. Toxicol. 49, 342-347. doi: 10.1016/j.fct.2010.11.003

Al-Ali, A., Alkhawajah, A. A., Randhawa, M. A., and Shaikh, N. A. (2008). Oral and intraperitoneal LD50 of thymoquinone, an active principle of Nigella sativa, in mice and rats. J. Ayub Med. Coll. Abbottabad 20, 25-27.

Al-Ashban, R. M., Abou-Shaaban, R. R., and Shah, A. H. (2010). Toxicity studies on Trigonella foenum-graecum L. seeds used in spices and as a traditional remedy for diabetes. Orient. Pharm. Exp. Med. 10, 66-78. doi: 10.3742/OPEM.2010.10.2.066

Al-Daghri, N. M., Alokail, M. S., Alkharfy, K. M., Mohammed, A. K., AbdAlrahman, S. H., Yakout, S. M., et al. (2012). Fenugreek extract as an inducer of cellular death via autophagy in human $\mathrm{T}$ lymphoma Jurkat cells. BMC Complement. Altern. Med. 12:202. doi: 10.1186/1472-6882-12-202

Alexander, S., and Friedl, P. (2012). Cancer invasion and resistance: interconnected processes of disease progression and therapy failure. Trends Mol. Med. 18, 13-26. doi: 10.1016/j.molmed.2011.11.003

Alhosin, M., Abusnina, A., Achour, M., Sharif, T., Muller, C., Peluso, J., et al. (2010). Induction of apoptosis by thymoquinone in lymphoblastic leukemia Jurkat cells is mediated by a p73-dependent pathway which targets the epigenetic integrator UHRF1. Biochem. Pharmacol. 79, 1251-1260. doi: 10.1016/j.bcp.2009.12.015

Ali, F., Khan, R., Khan, A. Q., Lateef, M. A., Maqbool, T., and Sultana, S. (2014). Assessment of augmented immune surveillance and tumor cell death by cytoplasmic stabilization of $\mathrm{p} 53$ as a chemopreventive strategy of 3 promising medicinal herbs in murine 2-stage skin carcinogenesis. Integr. Cancer Ther. 13, 351-367. doi: 10.1177/1534735413513831

Alkhatib, R., Joha, S., Cheok, M., Roumy, V., Idziorek, T., Preudhomme, C., et al. (2010). Activity of ladanein on leukemia cell lines and its occurrence in Marrubium vulgare. Planta Med. 76, 86-87. doi: 10.1055/s-00291185972

Al-Oqail, M. M., Farshori, N. N., Al-Sheddi, E. S., Musarrat, J., Al-Khedhairy, A. A., and Siddiqui, M. A. (2013). In vitro cytotoxic activity of seed oil of fenugreek against various cancer cell lines. Asian Pac. J. Cancer Prev. 14, 1829-1832. doi: 10.7314/APJCP.2013.14.3.1829

Alsemari, A., Alkhodairy, F., Aldakan, A., Al-Mohanna, M., Bahoush, E., Shinwari, Z., et al. (2014). The selective cytotoxic anti-cancer properties and proteomic analysis of Trigonella Foenum-Graecum. BMC Complement. Altern. Med. 14:114. doi: 10.1186/1472-6882-14-114

Alshatwi, A. A., Shafi, G., Hasan, T. N., Syed, N. A., and Khoja, K. K. (2013). Fenugreek induced apoptosis in breast cancer MCF-7 cells mediated independently by fas receptor change. Asian Pac. J. Cancer Prev. 14, 5783-5788. doi: 10.7314/APJCP.2013.14.10.5783

Al-Sheddi, E. S., Farshori, N. N., Al-Oqail, M. M., Musarrat, J., Al-Khedhairy, A. A., and Siddiqui, M. A. (2014). Cytotoxicity of Nigella sativa seed oil and extract against human lung cancer cell line. Asian Pac. J. Cancer Prev. 15, 983-987. doi: 10.7314/APJCP.2014.15.2.983
Amessis-Ouchemoukh, N., Ouchemoukh, S., Meziant, N., Idiri, Y., Hernanz, D., Stinco, C. M., et al. (2017). Bioactive metabolites involved in the antioxidant, anticancer and anticalpain activities of Ficus carica L., Ceratonia siliqua L. and Quercus ilex L. extracts. Ind. Crops Prod. 95, 6-17. doi: 10.1016/j.indcrop.2016.10.007

Amin, A., Alkaabi, A., Al-Falasi, S., and Daoud, S. A. (2005). Chemopreventive activities of Trigonella foenum graecum (Fenugreek) against breast cancer. Cell Biol. Int. 29, 687-694. doi: 10.1016/j.cellbi.2005.04.004

Amin, F., Islam, N., Anila, N., and Gilani, A. H. (2015). Clinical efficacy of the coadministration of Turmeric and Black seeds (Kalongi) in metabolic syndrome - a double blind randomized controlled trial - TAK-MetS trial. Complement. Ther. Med. 23, 165-174. doi: 10.1016/j.ctim.2015.01.008

Arafa, E. A., Zhu, Q., Shah, Z. I., Wani, G., Barakat, B. M., Racoma, I., et al. (2011). Thymoquinone up-regulates PTEN expression and induces apoptosis in doxorubicin-resistant human breast cancer cells. Mutat. Res. Fundam. Mol. Mech. Mutagen. 706, 28-35. doi: 10.1016/j.mrfmmm.2010.10.007

Badary, O. A., Al-Shabanah, O. A., Nagi, M. N., Al-Bekairi, A. M., and Elmazar, M. M. A. (1998). Acute and subchronic toxicity of thymoquinone in mice. Drug Dev. Res. 44, 56-61.

Badary, O. A., Nagi, M. N., Al-Shabanah, O. A., Al-Sawaf, H., a, Al-Sohaibani, M. O., and Al-Bekairi, A. M. (1997). Thymoquinone ameliorates the nephrotoxicity induced by cisplatin in rodents and potentiates its antitumor activity. Can. J. Physiol. Pharmacol. 75, 1356-1361. doi: 10.1139/y97-169

Badria, F. A., Ameen, M., and Akl, M. R. (2007). Evaluation of cytotoxic compounds from Calligonum comosum L. growing in Egypt. Z. Naturforsch. C 62, 656-660. doi: 10.1515/znc-2007-9-1005

Baharetha, H. M., Nassar, Z. D., Aisha, A. F., Ahamed, M. B. K., Al-Suede, F. S. R., Kadir, M. O. A., et al. (2013). Proapoptotic and Antimetastatic properties of supercritical $\mathrm{CO}_{2}$ extract of Nigella sativa Linn. against breast cancer cells. J. Med. Food 16, 1121-1130. doi: 10.1089/jmf.2012.2624

Bajbouj, K., Schulze-Luehrmann, J., Diermeier, S., Amin, A., and Schneider-Stock, R. (2012). The anticancer effect of saffron in two p53 isogenic colorectal cancer cell lines. BMC Complement. Altern. Med. 12:69. doi: 10.1186/1472-688212-69

Bassermann, F., Eichner, R., and Pagano, M. (2014). The ubiquitin proteasome system - implications for cell cycle control and the targeted treatment of cancer. Biochim. Biophys. Acta Mol. Cell Res. 1843, 150-162. doi: 10.1016/j.bbamcr.2013.02.028

Bathaie, S. Z., Miri, H., Mohagheghi, M. A., Mokhtari-Dizaji, M., Shahbazfar, A. A., and Hasanzadeh, H. (2013). Saffron aqueous extract inhibits the chemicallyinduced gastric cancer progression in the wistar albino rat. Iran. J. Basic Med. Sci. 16, 27-38. doi: 10.22038/ijbms.2013.245

Becker, T. M., Boyd, S. C., Mijatov, B., Gowrishankar, K., Snoyman, S., Pupo, G. M., et al. (2014). Mutant B-RAF-Mcl-1 survival signaling depends on the STAT3 transcription factor. Oncogene 33, 1158-1166. doi: 10.1038/onc.2013.45

Bekir, J., Mars, M., Souchard, J. P., and Bouajila, J. (2013). Assessment of antioxidant, anti-inflammatory, anti-cholinesterase and cytotoxic activities of pomegranate (Punica granatum) leaves. Food Chem. Toxicol. 55, 470-475. doi: 10.1016/j.fct.2013.01.036

Benarba, B., Aoues, A., Vazquez, A., Ambroise, G., and Meddah, B. (2012). Aristolochia longa aqueous extract triggers the mitochondrial pathway of apoptosis in BL41 Burkitt's lymphoma cells. Int. J. Green Pharm. 6:45. doi: 10.4103/0973-8258.97128

Benarba, B., Belabid, L., Righi, K., Bekkar, A. A., Elouissi, M., Khaldi, A., et al. (2015). Ethnobotanical study of medicinal plants used by traditional healers in Mascara (North West of Algeria). J. Ethnopharmacol. 175, 626-637. doi: 10.1016/j.jep.2015.09.030

Benarba, B., Pandiella, A., and Elmallah, A. (2016). Anticancer activity, phytochemical screening and acute toxicity evaluation of an aqueous extract of Aristolochia longa L. Int. J. Pharm. Phytopharm. Res. 6, 20-26. doi: 10.24896/eijppr.2016614

Benzakour, G., Amrani, M., and Oudghiri, M. (2012). A Histopathological analyses of in vivo anti-tumor effect of an aqueous extract of Aristolochia longa used in cancer treatment in traditional medicine in Morocco. Int. J. Plant Res. 2, 31-35. doi: 10.5923/j.plant.20120202.06

Benzakour, G., Benkirane, N., Amrani, M., and Oudghiri, M. (2011). Immunostimulatory potential of Aristolochia longa L. induced toxicity on liver, intestine and kidney in mice. J. Toxicol. Environ. Heal. Sci. 3, 214-222. 
Boudjelal, A., Henchiri, C., Sari, M., Sarri, D., Hendel, N., Benkhaled, A., et al. (2013). Herbalists and wild medicinal plants in M'Sila (North Algeria): an ethnopharmacology survey. J. Ethnopharmacol. 148, 395-402. doi: 10.1016/j.jep.2013.03.082

Bourgou, S., Pichette, A., Marzouk, B., and Legault, J. (2010). Bioactivities of black cumin essential oil and its main terpenes from Tunisia. S. Afr. J. Bot. 76, 210-216. doi: 10.1016/j.sajb.2009.10.009

Bournine, L., Bensalem, S., Peixoto, P., Gonzalez, A., Maiza-Benabdesselam, F., Bedjou, F., et al. (2013a). Revealing the anti-tumoral effect of Algerian Glaucium flavum roots against human cancer cells. Phytomedicine 20, 1211-1218. doi: 10.1016/j.phymed.2013.06.007

Bournine, L., Bensalem, S., Wauters, J. N., Iguer-Ouada, M., MaizaBenabdesselam, F., Bedjou, F., et al. (2013b). Identification and quantification of the main active anticancer alkaloids from the root of Glaucium flavum. Int. J. Mol. Sci. 14, 23533-23544. doi: 10.3390/ijms141223533

Boutennoun, H., Boussouf, L., Rawashdeh, A., Al-Qaoud, K., Abdelhafez, S., Kebieche, M., et al. (2017). In vitro cytotoxic and antioxidant activities of phenolic components of Algerian Achillea odorata leaves. Arab. J. Chem. 10, 403-409. doi: 10.1016/j.arabjc.2014.05.013

Chaouki, W., Leger, D. Y., Eljastimi, J., Beneytout, J., and Hmamouchi, M. (2010). Antiproliferative effect of extracts from Aristolochia baetica and Origanum compactum on human breast cancer cell line MCF-7. Pharm. Biol. 48, 269-274. doi: 10.3109/13880200903096588

Chatterjee, S., Kumar, M., and Kumar, A. (2012). Chemomodulatory effect of Trigonella foenum graecum (L.) seed extract on two stage mouse skin carcinogenesis. Toxicol. Int. 19:287. doi: 10.4103/0971-6580.103670

Chebat, A., Skalli, S., Errihani, H., Boulaâmane, L., Mokrim, M., Mahfoud, T., et al. (2014). Étude de prévalence des effets indésirables liés à l'utilisation des plantes médicinales par les patients de l'Institut National d'Oncologie, Rabat. Phytotherapie 12, 25-32. doi: 10.1007/s10298-013-0828-4

Chen, P. S., Shih, Y. W., Huang, H. C., and Cheng, H. W. (2011). Diosgenin, a steroidal saponin, inhibits migration and invasion of human prostate cancer PC-3 cells by reducing matrix metalloproteinases expression. PLoS ONE 6:e20164. doi: 10.1371/journal.pone.0020164

Cherif, H. S., Saidi, F., and Guedioura, A. (2014). Toxicological evaluation of Aristolochia longa L. extract in mice. Indian J. Appl. Res. 4, 26-30. doi: 10.15373/2249555X/MAY2014/8

Chevassus, H., Molinier, N., Costa, F., Galtier, F., Renard, E., and Petit, P. (2009). A fenugreek seed extract selectively reduces spontaneous fat consumption in healthy volunteers. Eur. J. Clin. Pharmacol. 65, 1175-1178. doi: 10.1007/s00228-009-0733-5

Cordell, G. (1995). Changing strategies in natural products chemistry. Phytochemistry 40, 1585-1612. doi: 10.1016/0031-9422(95)00444-C

Das, S., Dey, K. K., Dey, G., Pal, I., Majumder, A., MaitiChoudhury, S., et al. (2012). Antineoplastic and apoptotic potential of traditional medicines thymoquinone and diosgenin in squamous cell carcinoma. PLoS ONE 7:e46641. doi: 10.1371/journal.pone.0046641

Dastjerdi, M., Mehdiabady, E., Iranpour, F., and Bahramian, H. (2016). Effect of thymoquinone on P53 gene expression and consequence apoptosis in breast cancer cell line. Int. J. Prev. Med. 7:66. doi: 10.4103/2008-7802.180412

Dehghani, H., Hashemi, M., Entezari, M., and Mohsenifar, A. (2015). The comparison of anticancer activity of thymoquinone and nanothymoquinone on human breast adenocarcinoma. Iran. J. Pharm. Res. 14, 539-46.

Dicitore, A., Caraglia, M., Gaudenzi, G., Manfredi, G., Amato, B., Mari, D., et al. (2014). Type I interferon-mediated pathway interacts with peroxisome proliferator activated receptor- $\gamma$ (PPAR- $\gamma$ ): at the cross-road of pancreatic cancer cell proliferation. Biochim. Biophys. Acta Rev. Cancer 1845, 42-52. doi: 10.1016/j.bbcan.2013.11.003

Dollah, M. A., Parhizkar, S., and Izwan, M. (2013). Effect of Nigella sativa on the kidney function in rats. Avicenna J. Phytomed. 3, 152-158.

Domoto, T., Pyko, I. V., Furuta, T., Miyashita, K., Uehara, M., Shimasaki, T., et al. (2016). Glycogen synthase kinase-3 $\beta$ is a pivotal mediator of cancer invasion and resistance to therapy. Cancer Sci. 107, 1363-1372. doi: 10.1111/cas. 13028

Effenberger, K., Breyer, S., and Schobert, R. (2010). Terpene conjugates of the Nigella sativa seed-oil constituent thymoquinone with enhanced efficacy in cancer cells. Chem. Biodivers. 7, 129-139. doi: 10.1002/cbdv.2009 00328
El Babili, F. (2013). Lawsonia inermis: its anatomy and its antimalarial, antioxidant and human breast cancer cells MCF7 activities. Pharm. Anal. Acta 4, 4-9. doi: 10.4172/2153-2435.1000203

El Babili, F., Bouajila, J., Fouraste, I., Valentin, A., Mauret, S., and Moulis, C. (2010). Chemical study, antimalarial and antioxidant activities, and cytotoxicity to human breast cancer cells (MCF7) of Argania spinosa. Phytomedicine 17, 157-160. doi: 10.1016/j.phymed.2009.05.014

El Bairi, K., Ouzir, M., Agnieszka, N., and Khalki, L. (2017). Anticancer potential of Trigonella foenum graecum: cellular and molecular targets. Biomed. Pharmacother. 90, 479-491. doi: 10.1016/j.biopha.2017.03.071

El Euch, S. K., Bouajila, J., and Bouzouita, N. (2015). Chemical composition, biological and cytotoxic activities of Cistus salviifolius flower buds and leaves extracts. Ind. Crops Prod. 76, 1100-1105. doi: 10.1016/j.indcrop.2015.08.033

El Molla, S. G., Abdel Motaal, A., El Hefnawy, H., and El Fishawy, A. (2016). Cytotoxic activity of phenolic constituents from Echinochloa crusgalli against four human cancer cell lines. Rev. Bras. Farmacogn. 26, 62-67. doi: 10.1016/j.bjp.2015.07.026

Elansary, H. O., and Mahmoud, E. A. (2015). Egyptian herbal tea infusions antioxidants and their antiproliferative and cytotoxic activities against cancer cells. Nat. Prod. Res. 29, 474-479. doi: 10.1080/14786419.2014.951354

Elghuol, M. M., Khalil, K. A., Zain, M. M., and Mohamed Said, M. S. (2016). Apoptosis inducer capacity of cardiotonic steroids of Urginea maritima extract on SH-SY5Y neuroblastoma cells, with less susceptibility among neuronmodule cells. Am. J. Appl. Sci. 13, 686-696. doi: 10.3844/ajassp.2016.686.696

El-hawary, S. S., El-sofany, R. H., Abdel-Monem, A. R., Ashour, R. S., and Sleem, A. A. (2012). Polyphenolics content and biological activity of Plectranthus amboinicus (Lour.) spreng growing in Egypt (Lamiaceae). Pharmacogn. J. 4, 45-54. doi: 10.5530/pj.2012.32.9

El-Hilaly, J., Hmammouchi, M., and Lyoussi, B. (2003). Ethnobotanical studies and economic evaluation of medicinal plants in Taounate province (Northern Morocco). J. Ethnopharmacol. 86, 149-158. doi: 10.1016/S0378-8741(03)00012-6

El-Seedi, H. R., Burman, R., Mansour, A., Turki, Z., Boulos, L., Gullbo, J., et al. (2013). The traditional medical uses and cytotoxic activities of sixtyone Egyptian plants: discovery of an active cardiac glycoside from Urginea maritima. J. Ethnopharmacol. 145, 746-757. doi: 10.1016/j.jep.2012.12.007

Endrini, S., Rahmat, A., Ismail, P., and Yun Hin, T.-Y. (2002). Anticarcinogenic properties and antioxidant activity of henna (Lawsonia inermis). J. Med. Sci. 2, 194-197. doi: 10.3923/jms.2002.194.197

Endrini, S., Rahmat, A., Ismail, P., and Taufiq-Yap, Y. H. (2007). Comparing of the cytotoxicity properties and mechanism of Lawsonia inermis and Strobilanthes crispus extract against several cancer cell lines. J. Med. Sci. 7, 1098-1102. doi: 10.3923/jms.2007.1098.1102

Fathy, S. A., Singab, A. N. B., Agwa, S. A., Abd El Hamid, D. M., Zahra, F. A., and Abd El Moneim, S. M. (2013). The antiproliferative effect of mulberry (Morus alba L.) plant on hepatocarcinoma cell line HepG2. Egypt. J. Med. Hum. Genet. 14, 375-382. doi: 10.1016/j.ejmhg.2013.07.001

Festuccia, C., Mancini, A., Gravina, G. L., Scarsella, L., Llorens, S., Alonso, G. L., et al. (2014). Antitumor effects of saffron-derived carotenoids in prostate cancer cell models. Biomed Res. Int. 2014, 1-12. doi: 10.1155/2014/135048

Forman, D., and Ferlay, J. (2014). “The global and regional burden of cancer," in World Cancer Report 2014, eds B. W. Stewart and C. P. Wild (Lyon: International Agency for Research on Cancer), 7250-7257.

Ghali, W., Vaudry, D., Jouenne, T., and Marzouki, M. N. (2013). Assessment of cyto-protective, antiproliferative and antioxidant potential of a medicinal plant Jatropha podagrica. Ind. Crops Prod. 44, 111-118. doi: $10.1016 /$ j.indcrop.2012.10.020

Ghosh, S., and Dass, J. F. (2016). Study of pathway cross-talk interactions with NF- $\kappa$ B leading to its activation via ubiquitination or phosphorylation: a brief review. Gene 584, 97-109. doi: 10.1016/j.gene.2016.03.008

Gupta, A., Gupta, R., and Lal, B. (2001). Effect of Trigonella foenum-graecum (fenugreek) seeds on glycaemic control and insulin resistance in type 2 diabetes mellitus: a double blind placebo controlled study. J. Assoc. Physicians India 49, 1057-1061.

Gurung, R. L., Lim, S. N., Khaw, A. K., Soon, J. F., Shenoy, K., Mohamed Ali, S., et al. (2010). Thymoquinone induces telomere shortening, DNA damage and apoptosis in human glioblastoma cells. PLoS ONE 5:e12124. doi: 10.1371 /journal.pone.0012124 
Hammiche, V., and Maiza, K. (2006). Traditional medicine in Central Sahara: pharmacopoeia of Tassili N'ajjer. J. Ethnopharmacol. 105, 358-367. doi: 10.1016/j.jep.2005.11.028

Hibasami, H., Moteki, H., Ishikawa, K., Katsuzaki, H., Imai, K., Yoshioka, K., et al. (2003). Protodioscin isolated from fenugreek (Trigonella foenum graecum L.) induces cell death and morphological change indicative of apoptosis in leukemic cell line H-60, but not in gastric cancer cell line KATO III. Int. J. Mol. Med. 11, 23-26. doi: 10.3892/ijmm.11.1.23

Hirakawa, N., Okauchi, R., Miura, Y., and Yagasaki, K. (2005). Anti-invasive activity of niacin and trigonelline against cancer cells. Biosci. Biotechnol. Biochem. 69, 653-658. doi: 10.1271/bbb.69.653

Hu, K., and Yao, X. (2002). Protodioscin (NSC-698 796): its spectrum of cytotoxicity against sixty human cancer cell lines in an anticancer drug screen panel. Planta Med. 68, 297-301. doi: 10.1055/s-2002-26743

Islam, S. N., Begum, P., Ahsan, T., Huque, S., and Ahsan, M. (2004). Immunosuppressive and cytotoxic properties of Nigella sativa. Phyther. Res. 18, 395-398. doi: 10.1002/ptr.1449

Jamila, F., and Mostafa, E. (2014). Ethnobotanical survey of medicinal plants used by people in Oriental Morocco to manage various ailments. J. Ethnopharmacol. 154, 76-87. doi: 10.1016/j.jep.2014.03.016

Javan, M., Ahmadiani, A., Semnanian, S., and Kamalinejad, M. (1997). Antinociceptive effects of Trigonella foenum-graecum leaves. J. Ethnopharmacol. 58, 125-129. doi: 10.1016/S0378-8741(97)00089-5

Jrah Harzallah, H., Kouidhi, B., Flamini, G., Bakhrouf, A., and Mahjoub, T. (2011). Chemical composition, antimicrobial potential against cariogenic bacteria and cytotoxic activity of Tunisian Nigella sativa essential oil and thymoquinone. Food Chem. 129, 1469-1474. doi: 10.1016/j.foodchem.2011.05.117

Kabbaj, F. Z., Meddah, B., Cherrah, Y., El, M., and Faouzi, A. (2012). Ethnopharmacological profile of traditional plants used in Morocco by cancer patients as herbal therapeutics. Phytopharmacology 2, 243-256.

Khader, M., Bresgen, N., and Eckl, P. M. (2009). In vitro toxicological properties of thymoquinone. Food Chem. Toxicol. 47, 129-133. doi: 10.1016/j.fct.2008.10.019

Khader, M., Eckl, P. M., and Bresgen, N. (2007). Effects of aqueous extracts of medicinal plants on MNNG-treated rat hepatocytes in primary cultures. J. Ethnopharmacol. 112, 199-202. doi: 10.1016/j.jep.2007.01.027

Khalife, R., Hodroj, M. H., Fakhoury, R., and Rizk, S. (2016). Thymoquinone from Nigella sativa seeds promotes the antitumor activity of noncytotoxic doses of topotecan in human colorectal cancer cells in vitro. Planta Med. 82, 312-321. doi: 10.1055/s-0035-1558289

Khalil, M. I., Ibrahim, M. M., El-Gaaly, G. A., and Sultan, A. S. (2015). Trigonella foenum (Fenugreek) induced apoptosis in hepatocellular carcinoma cell line, HepG2, mediated by upregulation of p53 and proliferating cell nuclear antigen. Biomed Res. Int. 2015, 1-11. doi: 10.1155/2015/914645

Khalki, L., M'hamed, S. B., Bennis, M., Chait, A., and Sokar, Z. (2010). Evaluation of the developmental toxicity of the aqueous extract from Trigonella foenum-graecum (L.) in mice. J. Ethnopharmacol. 131, 321-325. doi: $10.1016 /$ j.jep.2010.06.033

Khlifi, D., Sghaier, R. M., Amouri, S., Laouini, D., Hamdi, M., and Bouajila, J. (2013). Composition and anti-oxidant, anti-cancer and anti-inflammatory activities of Artemisia herba-alba, Ruta chalpensis L. and Peganum harmala L. Food Chem. Toxicol. 55, 202-208. doi: 10.1016/j.fct.2013.01.004

Khoja, K. K., Shaf, G., Hasan, T. N., Syed, N. A., Al-Khalifa, A. S., Al-Assaf, A. H., et al. (2011). Fenugreek, a naturally occurring edible spice, kills MCF-7 human breast cancer cells via an apoptotic pathway. Asian Pac. J. Cancer Prev. 12, 3299-304.

Kilani, S., Ben Sghaier, M., Limem, I., Bouhlel, I., Boubaker, J., Bhouri, W., et al. (2008). In vitro evaluation of antibacterial, antioxidant, cytotoxic and apoptotic activities of the tubers infusion and extracts of Cyperus rotundus. Bioresour. Technol. 99, 9004-9008. doi: 10.1016/j.biortech.2008.04.066

Kilani-Jaziri, S., Neffati, A., Limem, I., Boubaker, J., Skandrani, I., and Sghair, M., Ben, et al. (2009). Relationship correlation of antioxidant and antiproliferative capacity of Cyperus rotundus products towards K562 erythroleukemia cells. Chem. Biol. Interact. 181, 85-94. doi: 10.1016/j.cbi.2009.04.014

Kortylewski, M., Jove, R., and Yu, H. (2005). Targeting STAT3 affects melanoma on multiple fronts. Cancer Metastasis Rev. 24, 315-327. doi: 10.1007/s10555-005-1580-1

Krifa, M., Alhosin, M., Muller, C. D., Gies, J.-P., Chekir-Ghedira, L., Ghedira, K., et al. (2013). Limoniastrum guyonianum aqueous gall extract induces apoptosis in human cervical cancer cells involving p16INK4A re-expression related to UHRF1 and DNMT1 down-regulation. J. Exp. Clin. Cancer Res. 32:30. doi: 10.1186/1756-9966-32-30

Krifa, M., Skandrani, I., Pizzi, A., Nasr, N., Ghedira, Z., Mustapha, N., et al. (2014). An aqueous extract of Limoniastrum guyonianum gall induces anti-tumor effects in melanoma-injected mice via modulation of the immune response. Food Chem. Toxicol. 69, 76-85. doi: 10.1016/j.fct.2014.03.033

Kundu, J., Choi, B. Y., Jeong, C.-H., Kundu, J. K., and Chun, K.-S. (2014). Thymoquinone induces apoptosis in human colon cancer HCT116 cells through inactivation of STAT3 by blocking JAK2- and Src mediated phosphorylation of EGF receptor tyrosine kinase. Oncol. Rep. 32, 821-828. doi: 10.3892/or.2014.3223

Lapierre, L. R., Kumsta, C., Sandri, M., Ballabio, A., and Hansen, M. (2015). Transcriptional and epigenetic regulation of autophagy in aging. Autophagy 11, 867-880. doi: 10.1080/15548627.2015.1034410

Lee, J., Gupta, S., Huang, J. S., Jayathilaka, L. P., and Lee, B. S. (2013). HPLC-MTT assay: anticancer activity of aqueous garlic extract is from allicin. Anal. Biochem. 436, 187-189. doi: 10.1016/j.ab.2013.01.033

Leger, D. Y., Liagre, B., Corbière, C., Cook-Moreau, J., and Beneytout, J.-L. (2004). Diosgenin induces cell cycle arrest and apoptosis in HEL cells with increase in intracellular calcium level, activation of cPLA2 and COX-2 overexpression. Int. J. Oncol. 25, 555-562. doi: 10.3892/ijo.25.3.555

Li, F., Rajendran, P., and Sethi, G. (2010). Thymoquinone inhibits proliferation, induces apoptosis and chemosensitizes human multiple myeloma cells through suppression of signal transducer and activator of transcription 3 activation pathway. Br. J. Pharmacol. 161, 541-554. doi: 10.1111/j.1476-5381.2010.00874.x

Liao, J. C., Lee, K. T., You, B. J., Lee, C. L., Chang, W., Wu, Y. C., et al. (2015). Raf/ERK/Nrf2 signaling pathway and MMP-7 expression involvement in the trigonelline-mediated inhibition of hepatocarcinoma cell migration. Food Nutr. Res. 59:29884. doi: 10.3402/fnr.v59.29884

Liu, M.-J., Wang, Z., Ju, Y., Wong, R. N.-S., and Wu, Q.-Y. (2005). Diosgenin induces cell cycle arrest and apoptosis in human leukemia K562 cells with the disruption of $\mathrm{Ca} 2+$ homeostasis. Cancer Chemother. Pharmacol. 55, 79-90. doi: 10.1007/s00280-004-0849-3

Loizzo, M. R., Rashed, K., Said, A., Bonesi, M., Menichini, F., and Tundis, R. (2014). Antiproliferative and antioxidant properties of Alhagi maurorum Boiss (Leguminosae) aerial parts. Ind. Crops Prod. 53, 289-295. doi: 10.1016/j.indcrop.2013.12.049

Manase, M. J., Mitaine-Offer, A.-C., Pertuit, D., Miyamoto, T., Tanaka, C., Delemasure, S., et al. (2012). Solanum incanum and S. heteracanthum as sources of biologically active steroid glycosides: confirmation of their synonymy. Fitoterapia 83, 1115-1119. doi: 10.1016/j.fitote.2012.04.024

Mansour, M. A., Ginawi, O. T., El-Hadiyah, T., El-Khatib, A. S., Al-Shabanah, O. A., and Al-Sawaf, H. A. (2001). Effects of volatile oil constituents of Nigella sativa on carbon tetrachloride-induced hepatotoxicity in mice: evidence for antioxidant effects of thymoquinone. Res. Commun. Mol. Pathol. Pharmacol. 110, 239-251.

Medini, F., Bourgou, S., Lalancette, K., Snoussi, M., Mkadmini, K., Coté, I., et al. (2015). Phytochemical analysis, antioxidant, anti-inflammatory, and anticancer activities of the halophyte Limonium densiflorum extracts on human cell lines and murine macrophages. S Afr. J. Bot. 99, 158-164. doi: 10.1016/j.sajb.2015.04.007

Merghoub, N., El Btaouri, H., Benbacer, L., Gmouh, S., Trentesaux, C., Brassart, B., et al. (2016). Inula viscosa extracts induces telomere shortening and apoptosis in cancer cells and overcome drug resistance. Nutr. Cancer 68, 131-143. doi: 10.1080/01635581.2016.1115105

Merzouki, A., Ed-derfoufi, F., and Molero Mesa, J. (2000). Contribution to the knowledge of Rifian traditional medicine. II: folk medicine in Ksar Lakbir district (NW Morocco). Fitoterapia 71, 278-307. doi: 10.1016/S0367-326X(00)00139-8

Moalic, S., Liagre, B., Corbiere, C., Bianchi, A., Danca, M., Bordji, K., et al. (2001). A plant steroid, diosgenin, induces apostosis, cell cycle arrest and cox activity in osteosarcoms cells. Fed. Eur. Biochem. Soc. Lett. 506, 205-230. doi: 10.1016/S0014-5793(01)02924-6

Mohtashami, R., Fallah Huseini, H., Heydari, M., Amini, M., Sadeqhi, Z., Ghaznavi, H., et al. (2015). Efficacy and safety of honey based formulation of Nigella sativa seed oil in functional dyspepsia: a double 
blind randomized controlled clinical trial. J. Ethnopharmacol. 175, 147-152. doi: 10.1016/j.jep.2015.09.022

Mozaffari, Z., Azarnia, M., and Angaji, S., a (2010). Evaluation of toxic effects of Trigonella foenum-graecum leaf aqueous extract on development of long bone tissue in rat fetus. J. Med. Plants Res. 4, 1148-1155. doi: 10.5897/ JMPR09.437

Muralidhara, Narasimhamurthy, K., Viswanatha, S., and Ramesh, B. (1999). Acute and subchronic toxicity assessment of debitterized fenugreek powder in the mouse and rat. Food Chem. Toxicol. 37, 831-838. doi: 10.1016/S0278-6915(99)00076-9

Oh, Y.-T., Yue, P., Wang, D., Tong, J.-S., Chen, Z. G., Khuri, F. R., et al. (2015). Suppression of death receptor 5 enhances cancer cell invasion and metastasis through activation of caspase-8/TRAF2-mediated signaling. Oncotarget 6, 41324-41338. doi: 10.18632/oncotarget.5847

Ouelbani, R., Bensari, S., Mouas, T. N., and Khelifi, D. (2016). Ethnobotanical investigations on plants used in folk medicine in the regions of Constantine and Mila (North-East of Algeria). J. Ethnopharmacol. 194, 196-218. doi: 10.1016/j.jep.2016.08.016

Ouzir, M., El Bairi, K., and Amzazi, S. (2016). Toxicological properties of fenugreek (Trigonella foenum graecum). Food Chem. Toxicol. 96, 145-154. doi: 10.1016/j.fct.2016.08.003

Ozaslan, M., Zumrutdal, M. E., Daglioglu, K., Kilic, I. H., Karagoz, I. D., Kalender, M. E., et al. (2009). Antitumoral Effect of $L$. inermis in Mice with EAC. Int. J. Pharmacol. 5, 263-267. doi: 10.3923/ijp.2009.263.267

Paarakh, P. M. (2010). Nigella sativa Linn.- A comprehensive review. Indian J. Nat. Prod. Resour. 1, 409-429.

Paramasivam, A., Sambantham, S., Shabnam, J., Raghunandhakumar, S., Anandan, B., Rajiv, R., et al. (2012). Anti-cancer effects of thymoquinone in mouse neuroblastoma (Neuro-2a) cells through caspase3 activation with down-regulation of XIAP. Toxicol. Lett. 213, 151-159. doi: 10.1016/j.toxlet.2012.06.011

Paunovic, V., Kosic, M., Djordjevic, S., Zugic, A., Djalinac, N., Gasic, U., et al. (2016). Marrubium vulgare ethanolic extract induces proliferation block, apoptosis, and cytoprotective autophagy in cancer cells in vitro. Cell. Mol. Biol. 62, 108-114. doi: $10.14715 / \mathrm{cmb} / 2016.62 .11 .18$

Periasamy, V. S., Athinarayanan, J., and Alshatwi, A. A. (2016). Anticancer activity of an ultrasonic nanoemulsion formulation of Nigella sativa L. essential oil on human breast cancer cells. Ultrason. Sonochem. 31, 449-455. doi: 10.1016/j.ultsonch.2016.01.035

Priya, R., Ilavenil, S., Kaleeswaran, B., Srigopalram, S., and Ravikumar, S. (2011). Effect of Lawsonia inermis on tumor expression induced by Dalton's lymphoma ascites in Swiss albino mice. Saudi J. Biol. Sci. 18, 353-359. doi: 10.1016/j.sjbs.2011.04.001

Qidwai, W., Hamza, H. B., Qureshi, R., and Gilani, A. (2009). Effectiveness, safety, and tolerability of powdered Nigella sativa (Kalonji) seed in capsules on serum lipid levels, blood sugar, blood pressure, and body weight in adults: results of a randomized, double-blind controlled trial. J. Altern. Complement. Med. 15, 639-644. doi: 10.1089/acm.2008 .0367

Racoma, I. O., Meisen, W. H., Wang, Q.-E., Kaur, B., and Wani, A. A. (2013). Thymoquinone inhibits autophagy and induces cathepsin-mediated, caspase-independent cell death in glioblastoma cells. PLoS ONE 8:e72882. doi: 10.1371/journal.pone.0072882

Raghunandhakumar, S., Paramasivam, A., Senthilraja, S., Naveenkumar, C., Asokkumar, S., Binuclara, J., et al. (2013). Thymoquinone inhibits cell proliferation through regulation of G1/S phase cell cycle transition in $\mathrm{N}$-nitrosodiethylamine-induced experimental rat hepatocellular carcinoma. Toxicol. Lett. 223, 60-72. doi: 10.1016/j.toxlet.2013.08.018

Rahmat, A., Endrini, S., Ismail, P., Yun Hin, T. Y., and Abu Bakar, M. F. (2006). Chemical constituents, antioxidant activity and cytotoxic effects of essential oil from Strobilanthes crispus and Lawsonia inermis. J. Biol. Sci. 6, 1005-1010. doi: $10.3923 /$ jbs.2006.1005.1010

Rahmati-Yamchi, M., Ghareghomi, S., Haddadchi, G., Milani, M., Aghazadeh, M., and Daroushnejad, H. (2014). Fenugreek extract diosgenin and pure diosgenin inhibit the hTERT gene expression in A549 lung cancer cell line. Mol. Biol. Rep. 41, 6247-6252. doi: 10.1007/s11033-014-3505-y

Rajput, S., Kumar, B. N. P., Dey, K. K., Pal, I., Parekh, A., and Mandal, M. (2013). Molecular targeting of Akt by thymoquinone promotes G1 arrest through translation inhibition of cyclin D1 and induces apoptosis in breast cancer cells. Life Sci. 93, 783-790. doi: 10.1016/j.lfs.2013.09.009

Raju, J., Patlolla, J. M. R., Swamy, M. V., and Rao, C. V. (2004). Diosgenin, a steroid saponin of Trigonella foenum graecum (Fenugreek), inhibits azoxymethaneinduced aberrant crypt foci formation in F344 rats and induces apoptosis in HT-29 human colon cancer cells. Cancer Epidemiol. Biomarkers Prev. 13, 1392-1398.

Randhawa, M. A., and Alghamdi, M. S. (2011). Anticancer activity of Nigella sativa (black seed) - a review. Am. J. Chin. Med. 39, 1075-1091. doi: 10.1142/S0192415X1100941X

Rao, A., Steels, E., Beccaria, G., Inder, W. J., and Vitetta, L. (2015). Influence of a specialized Trigonella foenum-graecum seed extract (Libifem), on testosterone, estradiol and sexual function in healthy menstruating women, a randomised placebo controlled study. Phyther. Res. 29, 1123-1130. doi: 10.1002/ptr.5355

Rao, A., Steels, E., Inder, W. J., Abraham, S., and Vitetta, L. (2016). Testofen, a specialised Trigonella foenum-graecum seed extract reduces age-related symptoms of androgen decrease, increases testosterone levels and improves sexual function in healthy aging males in a double-blind randomised clinical study. Aging Male 19, 134-142. doi: 10.3109/13685538.2015.1135323

Reichling, J., Schnitzler, P., Suschke, U., and Saller, R. (2009). Essential oils of aromatic plants with antibacterial, antifungal, antiviral, and cytotoxic properties - an overview. Forsch. Komplementarmed. 16, 79-90. doi: 10.1159/000207196

Reka, A., Goswami, M., Krishnapuram, R., Standiford, T., and Keshamouni, V. (2011). Molecular cross-regulation between PPAR-gamma and other signaling pathways: implications for lung cancer therapy. Lung Cancer 72, 154-159. doi: 10.1016/j.lungcan.2011.01.019

Rooney, S., and Ryan, M. F. (2005). Modes of action of alpha-hederin and thymoquinone, active constituents of Nigella sativa, against HEp-2 cancer cells. Anticancer Res. 25, 4255-4259.

Ruijtenberg, S., and van den Heuvel, S. (2016). Coordinating cell proliferation and differentiation: antagonism between cell cycle regulators and cell type-specific gene expression. Cell Cycle 15, 196-212. doi: 10.1080/15384101.2015.1120925

Sadiq, M., Reddy, Y. P., and Chandrasekhar, K. (2015). A study of Nigella sativa induced growth inhibition of MCF and HepG2 cell lines: an antineoplastic study along with its mechanism of action. Pharmacognosy Res. 7:193. doi: 10.4103/0974-8490.150541

Saeed, M. E. M., Abdelgadir, H., Sugimoto, Y., Khalid, H. E., and Efferth, T. (2015). Cytotoxicity of 35 medicinal plants from Sudan towards sensitive and multidrug-resistant cancer cells. J. Ethnopharmacol. 174, 644-658. doi: 10.1016/j.jep.2015.07.005

Samarghandian, S., Borji, A., Farahmand, S. K., Afshari, R., and Davoodi, S. (2013). Crocus sativus L. (Saffron) stigma aqueous extract induces apoptosis in alveolar human lung cancer cells through caspase-dependent pathways activation. Biomed Res. Int. 2013, 1-12. doi: 10.1155/2013/417928

Sebastian, K. S., and Thampan, R. V. (2007). Differential effects of soybean and fenugreek extracts on the growth of MCF-7 cells. Chem. Biol. Interact. 170, 135-143. doi: 10.1016/j.cbi.2007.07.011

Shabbeer, S., Sobolewski, M., Anchoori, R. K., Kachhap, S., Hidalgo, M., Jimeno, A., et al. (2009). Fenugreek: a naturally occurring edible spice as an anticancer agent. Cancer Biol. Ther. 8, 272-278. doi: 10.4161/cbt.8.3.7443

Shalabi, M., Khilo, K., Zakaria, M. M., Elsebaei, M. G., Abdo, W., and Awadin, W. (2015). Anticancer activity of Aloe vera and Calligonum comosum extracts separetely on hepatocellular carcinoma cells. Asian Pac. J. Trop. Biomed. 5, 375-381. doi: 10.1016/S2221-1691(15)30372-5

Sharma, R. D., Sarkar, A., Hazra, D. K., Misra, B., Singh, J. B., and Maheshwari, B. B. (1996). Toxicological evaluation of fenugreek seeds: a long term feeding experiment in diabetic patients. Phyther. Res. 10, 519-520.

Shishodia, S., and Aggarwal, B. B. (2006). Diosgenin inhibits osteoclastogenesis, invasion, and proliferation through the downregulation of Akt, IкB kinase activation and NF-KB-regulated gene expression. Oncogene 25, 1463-1473. doi: 10.1038/sj.onc.1209194

Sreelatha, S., Jeyachitra, A., and Padma, P. R. (2011). Antiproliferation and induction of apoptosis by Moringa oleifera leaf extract on human cancer cells. Food Chem. Toxicol. 49, 1270-1275. doi: 10.1016/j.fct.2011.03.006

Steels, E., Rao, A., and Vitetta, L. (2011). Physiological Aspects of male libido enhanced by standardized Trigonella foenum-graecum extract and mineral formulation. Phyther. Res. 25, 1294-1300. doi: 10.1002/ptr.3360 
Sur, P., Das, M., Gomes, A., Vedasiromoni, J. R., Sahu, N. P., Banerjee, S., et al. (2001). Trigonella foenum graecum (fenugreek) seed extract as an antineoplastic agent. Phyther. Res. 15, 257-259. doi: 10.1002/ptr.718

Swamy, S. M., and Tan, B. K. (2000). Cytotoxic and immunopotentiating effects of ethanolic extract of Nigella sativa L. seeds. J. Ethnopharmacol. 70, 1-7. doi: 10.1016/S0378-8741(98)00241-4

Swaroop, A., Bagchi, M., Kumar, P., Preuss, H. G., Tiwari, K., Marone, P. A., et al. (2014). Safety, efficacy and toxicological evaluation of a novel, patented antidiabetic extract of Trigonella Foenum-Graecum seed extract (Fenfuro(TM)). Toxicol. Mech. Methods 6516, 1-25. doi: 10.3109/15376516.2014.943443

Swaroop, A., Jaipuriar, A. S., Gupta, S. K., Bagchi, M., Kumar, P., Preuss, H. G., et al. (2015). Efficacy of a novel fenugreek seed extract (Trigonella foenumgraecum, Furocyst TM) in polycystic ovary syndrome (PCOS). Int. J. Med. Sci. 12, 825-831. doi: 10.7150/ijms.13024

Taamalli, A., Arráez-Román, D., Barrajón-Catalán, E., Ruiz-Torres, V., PérezSánchez, A., Herrero, M., et al. (2012). Use of advanced techniques for the extraction of phenolic compounds from Tunisian olive leaves: phenolic composition and cytotoxicity against human breast cancer cells. Food Chem. Toxicol. 50, 1817-1825. doi: 10.1016/j.fct.2012.02.090

Tahraoui, A., El-Hilaly, J., Israili, Z. H., and Lyoussi, B. (2007). Ethnopharmacological survey of plants used in the traditional treatment of hypertension and diabetes in south-eastern Morocco (Errachidia province). J. Ethnopharmacol. 110, 105-117. doi: 10.1016/j.jep.2006.09.011

Talib, W. H., and Mahasneh, A. M. (2010). Antiproliferative activity of plant extracts used against cancer in traditional medicine. Sci. Pharm. 78, 33-45. doi: 10.3797/scipharm.0912-11

Tauseef Sultan, M., Butt, M. S., and Anjum, F. M. (2009). Safety assessment of black cumin fixed and essential oil in normal Sprague dawley rats: serological and hematological indices. Food Chem. Toxicol. 47, 2768-2775. doi: $10.1016 /$ j.fct.2009.08.011

Teixidor-Toneu, I., Martin, G. J., Ouhammou, A., Puri, R. K., and Hawkins, J. A. (2016). An ethnomedicinal survey of a Tashelhit-speaking community in the High Atlas, Morocco. J. Ethnopharmacol. 188, 96-110. doi: 10.1016/j.jep.2016.05.009

Thabrew, M. I., Mitry, R. R., Morsy, M. A., and Hughes, R. D. (2005). Cytotoxic effects of a decoction of Nigella sativa, Hemidesmus indicus and Smilax glabra on human hepatoma HepG2 cells. Life Sci. 77, 1319-1330. doi: 10.1016/j.lfs.2005.01.022

Tigrine, C., Bulzomi, P., Leone, S., Bouriche, H., Kameli, A., and Marino, M. (2013). Cleome arabica leaf extract has anticancer properties in human cancer cells. Pharm. Biol. 51, 1508-1514. doi: 10.3109/13880209.2013.796563

Touihri, I., Kallech-Ziri, O., Boulila, A., Fatnassi, S., Marrakchi, N., Luis, J., et al. (2015). Ecballium elaterium (L.) A. rich. seed oil: chemical composition and antiproliferative effect on human colonic adenocarcinoma and fibrosarcoma cancer cell lines. Arab. J. Chem. doi: 10.1016/j.arabjc.2015.02.023

Vahdati-Mashhadian, N., Rakhshandeh, H., and Omidi, A. (2005). An investigation on LD50 and subacute hepatic toxicity of Nigella sativa seed extracts in mice. Pharmazie 60, 544-547.
Walsh, C. M. (2014). Grand challenges in cell death and survival: apoptosis vs. necroptosis. Front. Cell Dev. Biol. 2:3. doi: 10.3389/fcell.2014.00003

Woo, C. C., Loo, S. Y., Gee, V., Yap, C. W., Sethi, G., Kumar, A. P., et al. (2011). Anticancer activity of thymoquinone in breast cancer cells: possible involvement of PPAR- $\gamma$ pathway. Biochem. Pharmacol. 82, 464-475. doi: 10.1016/j.bcp.2011.05.030

Yadav, U. C. S., and Baquer, N. Z. (2014). Pharmacological effects of Trigonella foenum-graecum L. in health and disease. Pharm. Biol. 52, 243-254. doi: 10.3109/13880209.2013.826247

Yamamoto, K., Mizumoto, A., Nishimura, K., Uda, A., Mukai, A., Yamashita, K., et al. (2014). Association of toxicity of sorafenib and sunitinib for human keratinocytes with inhibition of signal transduction and activator of transcription 3 (STAT3). PLoS ONE 9:e102110. doi: 10.1371/journal.pone.0102110

Yamani, A., Bunel, V., Antoine, M.-H., Husson, C., Stévigny, C., Duez, P., et al. (2015). Substitution between Aristolochia and Bryonia genus in NorthEastern Morocco: toxicological implications. J. Ethnopharmacol. 166, 250-260. doi: 10.1016/j.jep.2015.03.036

Yessoufou, K., Elansary, H. O., Mahmoud, E. A., and Skalicka-Woaniak, K. (2015). Antifungal, antibacterial and anticancer activities of Ficus drupacea L. stem bark extract and biologically active isolated compounds. Ind. Crops Prod. 74, 752-758. doi: 10.1016/j.indcrop.2015.06.011

Yun, S. J., Moon, S.-K., and Kim, W.-J. (2013). Investigational cell cycle inhibitors in clinical trials for bladder cancer. Expert Opin. Investig. Drugs 22, 369-377. doi: 10.1517/13543784.2013.751097

Zaoui, A., Cherrah, Y., Mahassini, N., Alaoui, K., Amarouch, H., and Hassar, M. (2002). Acute and chronic toxicity of Nigella sativa fixed oil. Phytomedicine 9, 69-74. doi: 10.1078/0944-7113-00084

Zarai, Z., Kadri, A., Ben Chobba, I., Ben Mansour, R., Bekir, A., Mejdoub, H., et al. (2011). The in-vitro evaluation of antibacterial, antifungal and cytotoxic properties of Marrubium vulgare L. essential oil grown in Tunisia. Lipids Health Dis. 10:161. doi: 10.1186/1476-511X-10-161

Zubair, H., Khan, H. Y., Sohail, A., Azim, S., Ullah, M. F., Ahmad, A., et al. (2013). Redox cycling of endogenous copper by thymoquinone leads to ROS-mediated DNA breakage and consequent cell death: putative anticancer mechanism of antioxidants. Cell Death Dis. 4:e660. doi: 10.1038/cddis. 2013.172

Conflict of Interest Statement: The authors declare that the research was conducted in the absence of any commercial or financial relationships that could be construed as a potential conflict of interest.

Copyright $(2017$ Alves-Silva, Romane, Efferth and Salgueiro. This is an open-access article distributed under the terms of the Creative Commons Attribution License (CC $B Y)$. The use, distribution or reproduction in other forums is permitted, provided the original author(s) or licensor are credited and that the original publication in this journal is cited, in accordance with accepted academic practice. No use, distribution or reproduction is permitted which does not comply with these terms. 